\title{
Geology and sedimentary environment of the Surma Group of rocks, Bandarban anticline, Bandarban, Bangladesh
}

\author{
Md. Masidul Haque ${ }^{1,2, *}$, Mrinal Kanti Roy ${ }^{2}$ \\ ${ }^{1}$ Department of Science and Technology, Graduate School of Medicine, Science and Technology, \\ Shinshu University, 3-1-1 Asahi, Matsumoto 390-8621, Japan \\ ${ }^{2}$ Department of Geology and Mining, University of Rajshahi-6205, Bangladesh \\ *Corresponding author's email: md_hq@ru.ac.bd
}

\begin{abstract}
The study illustrates the effect of tectonics, climate, and relative sea-level change on the depositional process of the Miocene Bhuban and Boka Bil Formation of Bengal Basin. Outcrop sediments of five transverse sections exposed along the axial zone of Bandarban anticline were studied. Twelve lithofacies such as Gm, Gms, Sm, ST, Sp, Sr, Sl, Sf, Sll, Fw, Fl and Fm have been identified within the successions and grouped into (i) turbidite generated, (ii) outer fan distal lobe basin plain and (iii) tide-influenced facies association. The analyses reveal that the sediments of the Bhuban Formation was turbiditegenerated that deposited below the continental shelf-slope environment. The Lower Bhuban Member consists of gray to brownish-gray calcareous sandstone with shale deposited under the channelized lobe of submarine fan. The Middle Bhuban Member dominated by black shale-siltstone deposited in distal turbidite lobe due to change the flow regime. The Upper Bhuban Member consists of yellow to yellowish gray, coarse to medium-grained sandstone-siltstone with black shale that deposited under channelized to nonchannelized lobes of submarine fan. The increasing sedimentation during the formation of the Upper Bhuban Member could be resulted due to increased intensity of the Asian Monsoon that carried enormous volume of sediment from the Himalaya. The Boka Bil Formation was deposited under estuary to tidal flat environment. The area was uplifted during and/or after subduction of the Indian Plate beneath the Burmese Plate. The monsoonal intensity enhances sedimentation that moved prograding delta towards the south. These processes shifted depositional environment from continental shelf-slope to marginal shallow marine during deposition of the Boka Bil Formation. The continental slope aligned east-west direction and sediments likely derived from the Himalaya and Trans-Himalaya in the present geographical setup during deposition of the sediments.
\end{abstract}

Keywords: Lithofacies; Depositional environment; Paleocurrent; Surma Group; Chittagong Hill Tracts

Received: 8 March, 2021 Received in revised form: 10 July, 2021 Accepted: 11 July, 2021

\section{INTRODUCTION}

The Miocene Bhuban and Boka Bil formations of the Surma Group are well exposed at the Chittagong Hill Tracts of Bangladesh. The Himalaya collision history is well preserved in the sediments deposited in subsiding foreland basin to the south, including the Bengal Basin of Bangladesh (Uddin and Lundberg, 1998), the western part of the Indo-Burmese Range, and the Bengal fan (Curray, 1991, 2005; Searle et al., 2007). The study area is part of the Bengal Basin that receives a huge quantity of sediments through ancient fluvial systems (Curray, 1994). The sediment deposited in the western part of Indo-Burmese Range uplifted during subduction of the Indian ocean plate beneath the Burmese Plate during the late Miocene to Pliocene and the Neogene sediments are exposed at the eastern folded belt of Bangladesh (Gani and Alam, 1999; Curray, 2014). The gas discoveries in the late 1990s in this region have triggered hydrocarbon exploration activities in southeastern Bengal Basin, also necessitate giving importance to a detailed study of both the sedimentological and stratigraphic approach for further exploration development activity in this area. Shale and sandstone-siltstone of the Surma Group have formed the source and reservoir rocks of the petroleum systems of Bangladesh (Shamsuddin, 2001; Team USGS-Bangladesh Gas Assessment, 2001). Considerable controversy exists on some aspects of the sedimentology and depositional environment of the Surma Group of rocks in the southeastern part of the Bengal Basin. The previous workers have reported that the sediment of the Bhuban and Boka Bil Formations were deposited under fluvio-deltaic (Assam Basin) to delta front environment (Surma Basin) (e.g., Alam et al., 2003; Devies et al., 2003; Gani and Alam, 2003) whereas the Miocene Lower Siwalik at Arunachal Himalaya foreland basin deposited under shallow marine deltaic environment (Taral et al., 2019). But the seismic interpretation of the Hatia Trough that is located to the west of the Chittagong-Tripura Folded Belt showed a deltaic shelf-slope environment during the deposition of Surma Group's sediment (Najman et al., 2012). The delta shelf depositional system prograding southward is very related to the upliftment of the Himalaya (Khin et al., 2014). The Neogene sediment of the Chittagong Hill Tracts and its surrounding 
areas has been widely studied to interpret the geology and sedimentary environment (e.g., Evans, 1964; Holtrop and Keizer, 1970; Johnson and Alam, 1991; Alam and Ferdous, 1995, 1996; Shamsuddin and Abdullah, 1997; Gani and Alam, 1999, 2003; Gani, 1999; Alam et al., 2003; Davies et al., 2003; Haque et al., 2010), tectonics (e.g., Uddin and Lundberg, 2004; Najman et al., 2012) and provenance (e.g., Uddin and Lundberg, 1998; Armstrong-Altrin et al., 2004; Rahman and Suzuki, 2007; Hossain et al., 2010; Hossain et al., 2017). However, detailed geology and sedimentological study of the Bhuban and Boka Bil Formations of the Bandarban anticline is very limited (e.g., Haque et al., 2010; Haque and Roy, 2020) and no one gives proper attention to interpret the possible causes of the environment change during deposition of Miocene sediment. The study area is bounded within latitude $22^{\circ} 04^{\prime} \mathrm{N}$ to $22^{\circ} 12^{\prime} \mathrm{N}$ and longitude $92^{\circ} 10^{\prime} \mathrm{E}$ to $92^{\circ} 18^{\prime} \mathrm{E}$ (Fig. 1). The study aims to convey the detailed sedimentology of the Miocene sediments and compare these to others to characterize the sedimentary environment. These aims achieve through (1) detailed logging and paleoenvironment analysis of the sediment that crop out in the Bandarban anticline's axial zone; and (2) understand the influence of tectonics, climate as well as relative sea-level change during deposition of sediment. Lithofacies, facies associations, facies model, and paleocurrent analysis have been used to reconstruct depositional environments.

\section{MATERIALS AND METHODS}

The fieldwork was carried out along the five transverse sections within the central part of the Bandarban anticline by compass-clinometer traverse method (Fig. 1). Due to the dense vegetation cover, the outcrops of the investigated area are not expose for invetigation. Rocks exposed in the road cut section, stream cut valley, and hillslope were studied (Fig. 1). Field data were acquired based on the topographic map of 1:50000 scale. The rocks were identified by their color, texture, and composition following Blatt et al. (1980), Pettijohn (1984), Walker (1984), Reading (1996) and Boggs (2001). Lithofacies of different sites were studied by naked eye and using pocket lenses. The cementing materials of the rocks were identified by color, hardness, and using hydrochloric acid. The sedimentary structures are recognized following Reineck and Singh (1980), and Collinson and Thompson (1982). The thickness of beds was measured by measuring tape; attitude and paleocurrent data are measured by clinometer. Paleocurrent data were analyzed following the scheme of Potter and Pettijohn (1977). Systematic mapping, sampling, and photographs have been carried out during the field investigation. Detailed lithology of the five studied sections along with delineated facies, facies model and paleocurrent rose diagram and paleogeographic model have been constructed and shown in Figures 4 - 6.

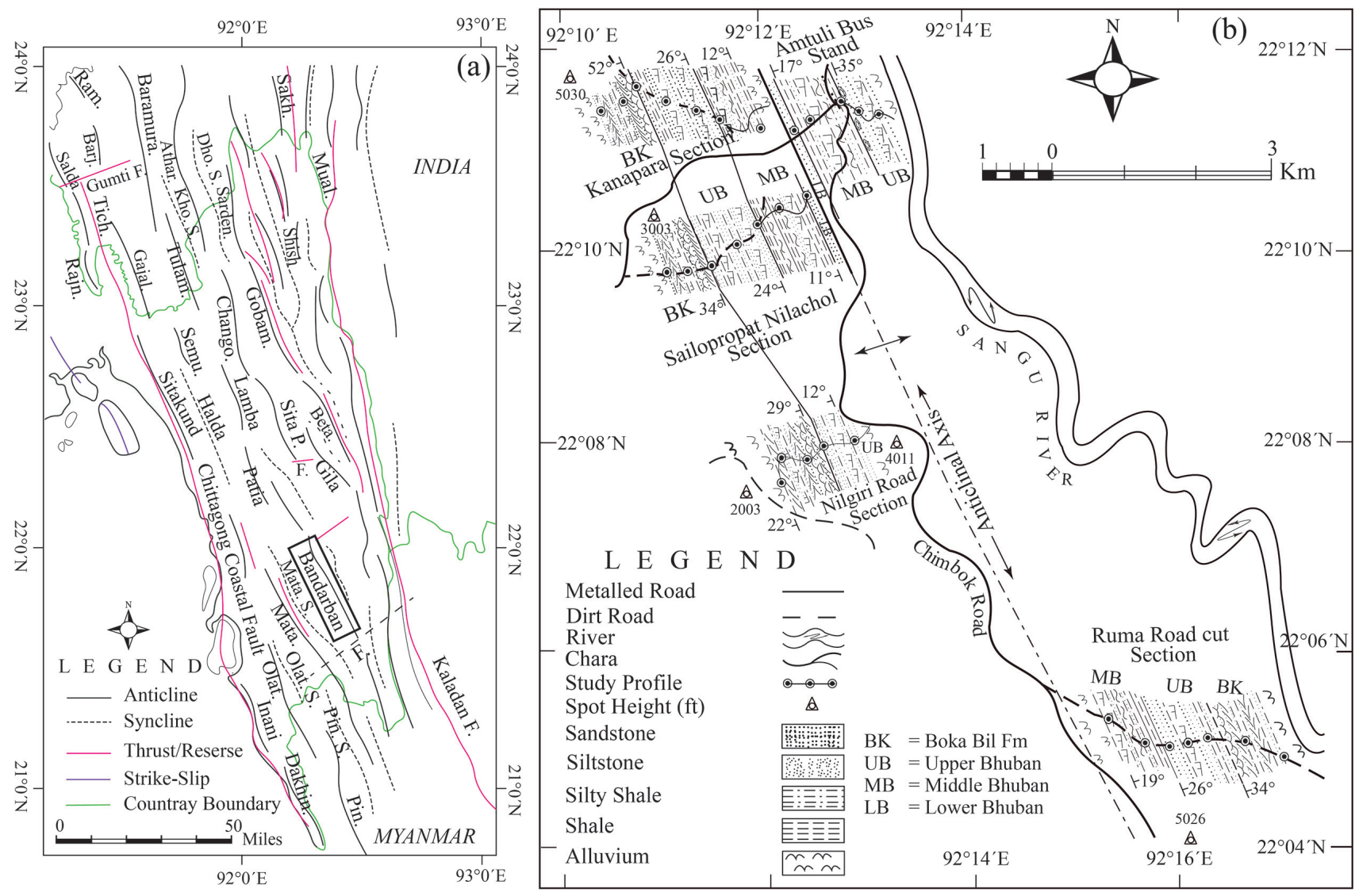

Fig. 1: (a) Simplified tectonic map of the southeastern folded belt of the Bengal Basin and its surroundings (Hossain et al., 2019). (b) Geological map of the axial zone of Bandarban anticline, Bandarban. 


\section{GEOLOGY AND STRATIGRAPHY}

The Bengal Basin initiation during the Gondwana continental landmass fragmented at the late Mesozoic (ca. $125 \mathrm{Ma}$ ) that incorporates the major part of Bangladesh and eastern part of India (Lindsay et al., 1991). The collision of Indian and Eurasian plates at $\sim 55-52$ Ma resulted in the formation of Himalaya ranges during $\sim 27-17$ Ma providing the major sedimentary sources to the basin (Beck et al., 1995, Najman et al., 1997, 2012; Roy and Chatterjee, 2015). Bengal Basin's sediment has been compressed and uplifted after an oblique collision between the Indian and Burmese Plate resulting forming of the Indo-Burmese Range. The continuous subduction of the Indian Plate that has the thick sediment of the Bengal Basin formed the Chittagong-Tripura Folded Belt, located west of the Indo-Burmese Range. The Bandarban is one of the prominent anticline structures in the southeastern folded of Bangladesh as well as the Chittagong Hill Tracts (Fig. 1a). Tectonically, the structure lies within the Chittagong Hill Tracts of Bengal Basin, which is considered to be the westernmost continuation of the Arakan-Yoma Folded Belt of Indo-Burmese Range (Fig 1a) (Curray et al., 1982; Dasgupta and Nandy, 1995; Hossain et al., 2019). The basin is believed to have evolved largely over a remnant ocean basin and rifted continental margin of eastern India (Graham et al., 1975), with at least its northern and northwestern portion underlain by continental crust (Khan and Agarwal, 1993;
BOGMC, 2000) and the southern and southeastern part underlain by oceanic crust (Curray et al., 1982; Curray, 2014). The anticlinal axis is trending about $\mathrm{N} 27^{\circ} \mathrm{W}-\mathrm{S} 27^{\circ} \mathrm{E}$ with a plunge in structure. The amount of dip of the strata in eastern and western flanks varies from $10^{0}-52^{\circ}$ and the amount of dip is higher in western flank than in the eastern (Fig. 1b).

The Surma Groups of rocks are well exposed in the Bandarban anticline. Sandstone, siltstone, silty shale and shale occasionally conglomerates occur monotonously throughout both flanks of the anticline. The stratigraphy of the anticline is established based on the exposed rock sequences and correlation with the generalized stratigraphic succession (Khan and Muminullah, 1988; Reimann, 1993; Uddin and Lundberg, 1999) (Fig. 2). Based on the lithology, the sequence is divided into two major units-Bhuban and Boka Bil Formations. Lithologically, the Bhuban Formation is subdivided into three units-Lower Bhuban Member (LBM), Middle Bhuban Member (MBM) and Upper Bhuban Member (UBM), and the Boka Bil Formation overlies the Bhuban Formation (Fig. 2). The hilltops are covered by the UBM sandstone; valleys by the MBM shale and basal part of the valley in axial zone occupied by the LBM sandstone. The Boka Bil Formation is available in some sections above the UBM, especially on the top and hillslope (Fig. 1). The stratigraphic profile, lithologic character, thickness and age of the sedimentary units are shown in fig. 2 .

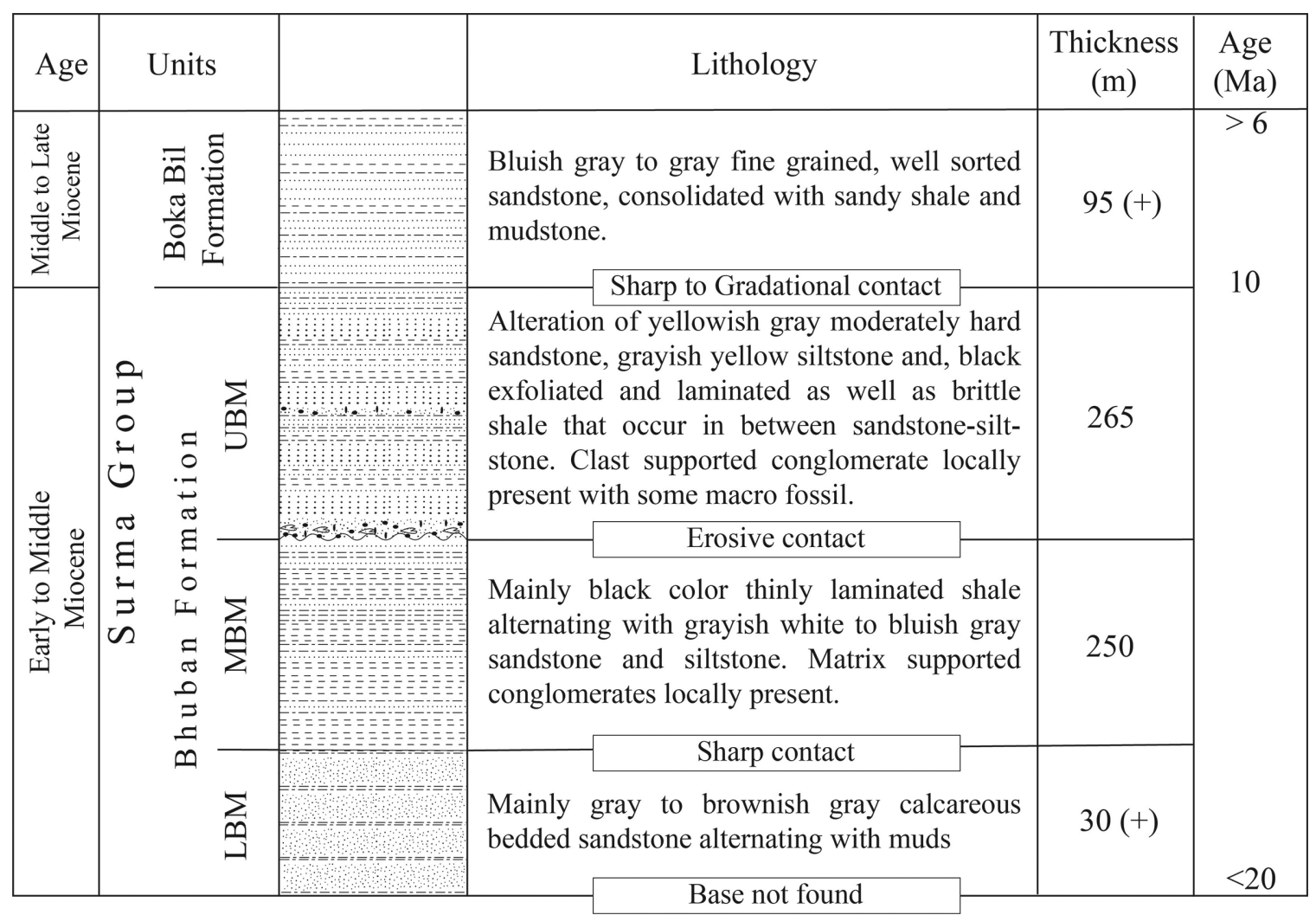

Fig. 2: Stratigraphic profile of the Bhuban and Boka Bil Formations in Bandarban anticline (modified after Haque et al., 2010; Khin et al., 2014). 


\section{FACIES ANALYSIS AND FACIES SCHEME}

Basis of lithological characters, grain size, nature of bed contact and sedimentary structure, a total of twelve lithofacies have been identified in the Bhuban and Boka Bil Formations of this area following the scheme of Allen (1970), Cant and Walker (1976); Miall (1978), Rust (1978), Reineck and Singh (1980), Stow (1986), Reading (1996) (Fig. 3). The summarized lithofacies code have shown in Table 1 and litho-columns shown in Fig. 4. Descriptions of lithofacies types are as followed.

\section{Clast Supported Conglomerate Facies (Gm)}

Conglomerates are less abundant than other lithotypes in the total litho-columns and are exposed in the contact zone of the MBM and UBM of the stratigraphic column (Fig. 3a). They are composed of shale clasts, pebbles, and granules of pre-existing rocks especially siltstone, sandstone. The color varies from brown to brownish black. The size of the clast ranges from $0.5 \mathrm{~cm}$ to $2 \mathrm{~cm}$ (Fig. 3a). The lower part of the UBM sandstone containing macrofossils of pelecypods is found with this facies. It was found at the Amtuli Bus Stand and Kanapara section of the study area (Fig. 3).

Walker $(1975 ;$ 1978) suggested coarse-grained turbidite model when the conglomerate facies shows the features of the disorganized characters of the coarse-grained sediments. Partly fluid turbulent and partly clast collisions might have the supported mechanism. Upon quick deposition, the clasts immediately stopped moving and the fabric was frozen in the deposit producing disorganized beds of conglomerates. Pelecypods' fossil character showed that they have been transported from the shoreface area and deposited below the continental slope in the submarine fan environment (Moore et al., 1997; Shanmugam, 2006; 2016).

\section{Matrix Supported Conglomerate (Gms)}

Matrix-supported conglomerates are less abundant in the study area. The matrix-supported conglomerates alternate with sandstone and silty sandstone to siltstone. They have composed of pebbles and granulesized clasts of pre-existing rock especially siltstone, sandstone and shales. Clasts are poorly sorted and randomly oriented and subangular to subrounded in shape (Fig. 3d). The thickness of the lithofacies varies from 0.1 to $0.5 \mathrm{~m}$.

Poorly sorting and random orientation of matrixsupported conglomerate suggests that this facies was deposited by mudflow or mass movement (Reineck and Singh, 1980; Boggs, 2001; Shanmugam, 2006, 2016). The disorganized nature of the clasts of the matrix-supported gravel is typical of debris flow deposition occurring in the proximal part of the submarine fan (Walker, 1984). Matrix supported conglomerate results from the deposition of gravelbed load by an energetic aqueous flow that keeps sand in suspension (Reading, 1996).

\section{Massive Sandstone Facies (Sm)}

The massive sandstone facies is exposed in the LBM and UBM of the Bandarban anticline (Fig. 3a-c). Gray, yellowish gray to brownish gray-colored sandstone has occurred as channel-shaped bodies. The thickness of medium to fine-grained sandstone beds ranges from $20 \mathrm{~cm}$ to few meters (Fig. 3c).

A turbidity current that normally maintains its sand load in suspension by fluid turbulence can pass through a stage of fluidized flow during the final few moments (second or minute) of flow immediately preceding deposition. The source area of sandstones was subjected to a major collision event at the time of deposition (Kuehl et al., 1989). This collision uplifts the mountains that subsequently subjected to tremendous erosion and cause the rapid transport of a huge influx of sediments into the river that changed to turbidity channel downward and thus deposited as massive sandstone at the basinal turbidite system near the proximal fan (Klein, 1982; Shanmugam, 2008, 2016).

\section{Turbidite Sandstone (ST)}

Medium to fine-grained, grayish-white colored turbidite sandstone is well exposed in the study area. It is embedded as channels of different sizes and shape within the shale and characterized by massive to graded bedding in the bottom and gradually change to flat bedding, ripple cross lamination with occasionally parallel lamination at the top of the successions (Fig. 3f). Sandstone bodies have a sharp base with normal grading, and finer silt and mud in upward. Within the sandstone bodies, the combination of graded bedding, ripple cross to parallel lamination are observed locally. The channelized sandstone bodies of these turbidite facies are separated from each other by hemipelagic to pelagic bluish-black to black shale.

Sandstone bodies structured by graded bedding, flat bedding, ripple cross laminations graded upward into parallel laminated silt and mud have been reported by many authors. Bouma (1962) proposed an excellent facies model for this type of sandstone known as the Bouma sequence for classical turbidites (Walker, 1984; Stow, 1986). The facies shows a deposition by a turbidity current in the marine condition below the continental slope. If there is a high rate of deposition from suspension during rippling, climbing ripple cross lamination is formed (Reineck and Singh, 1980; Wetzel and Uchman, 2012). 

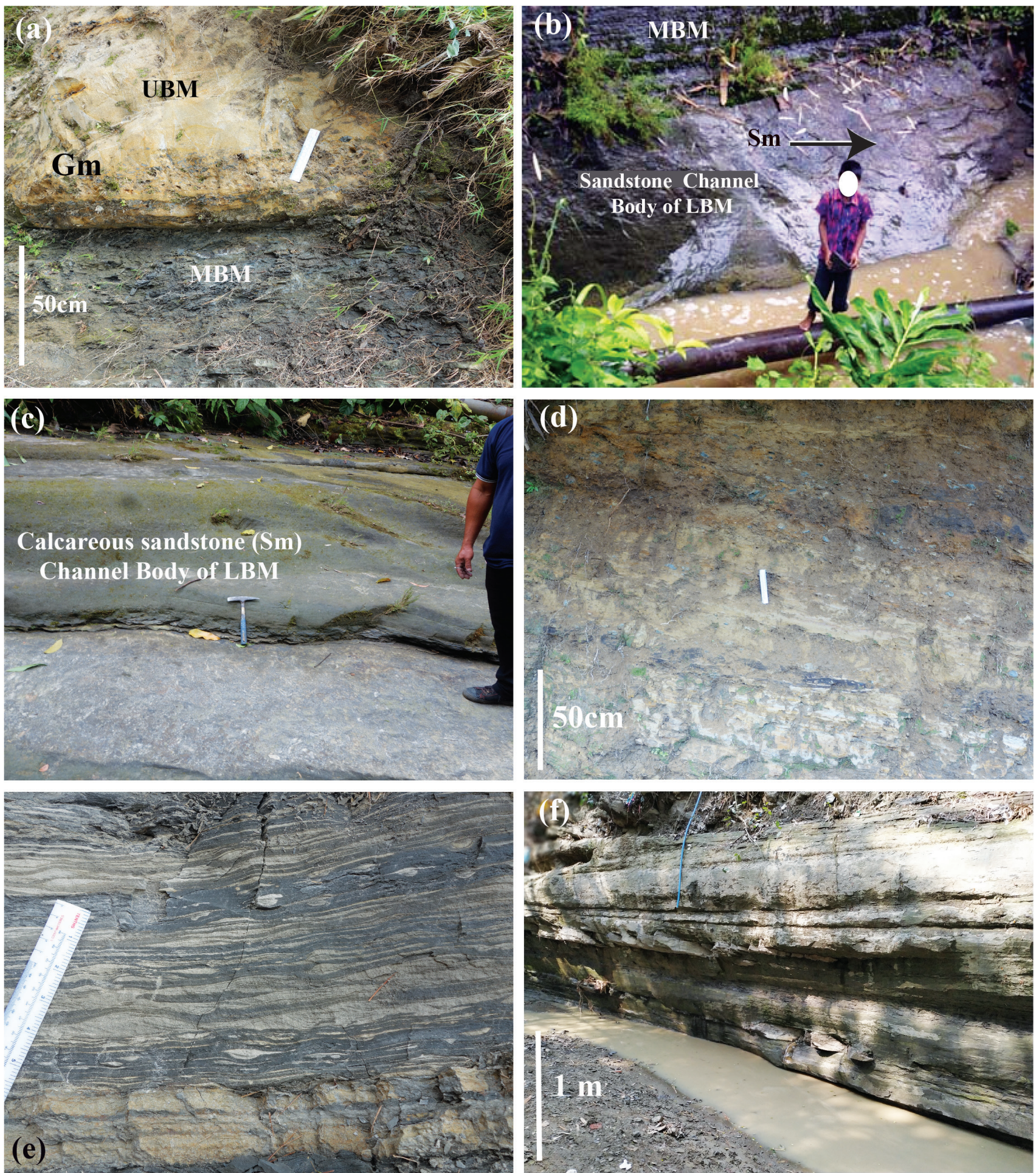

Fig. 3: (a) Erosive contact between black shale of the MBM and sand dominated UBM at Amtuli Bus Stand. Conglomerate dominated sand bodied is found in the lower part of UBM; (b) Channel shaped hart and calcareous, medium to fine-grained massive sandstone of the LBM overlain by shale dominated MBM in the axial zone at Amtuli section suggesting channelized mid submarine fan deposit for the LBM and distal lobe of basin plain deposit for the MBM; (c) Gray to yellowish-gray channel shaped calcareous sandstone of the LBM alternated with laminated greenish gray colored shale at Amtuli section; (d) Matrix supported conglomerate facies within the UBM at Sailopropat section; (e) A vertical litho-section of alteration laminated, wavy laminated to massive shale with lenticular to parallel laminated sandstone-siltstone facies at the MBM in Amtuli Bus Stand section; (f) shallow scoured to flat-based small turbidity channel filled with calcareous gray-colored sandstone alternation with black shale in Nilachol section. The sediment deposited in proximal to medial fan setup and the percentage of shale increases up of the litho-succession. 

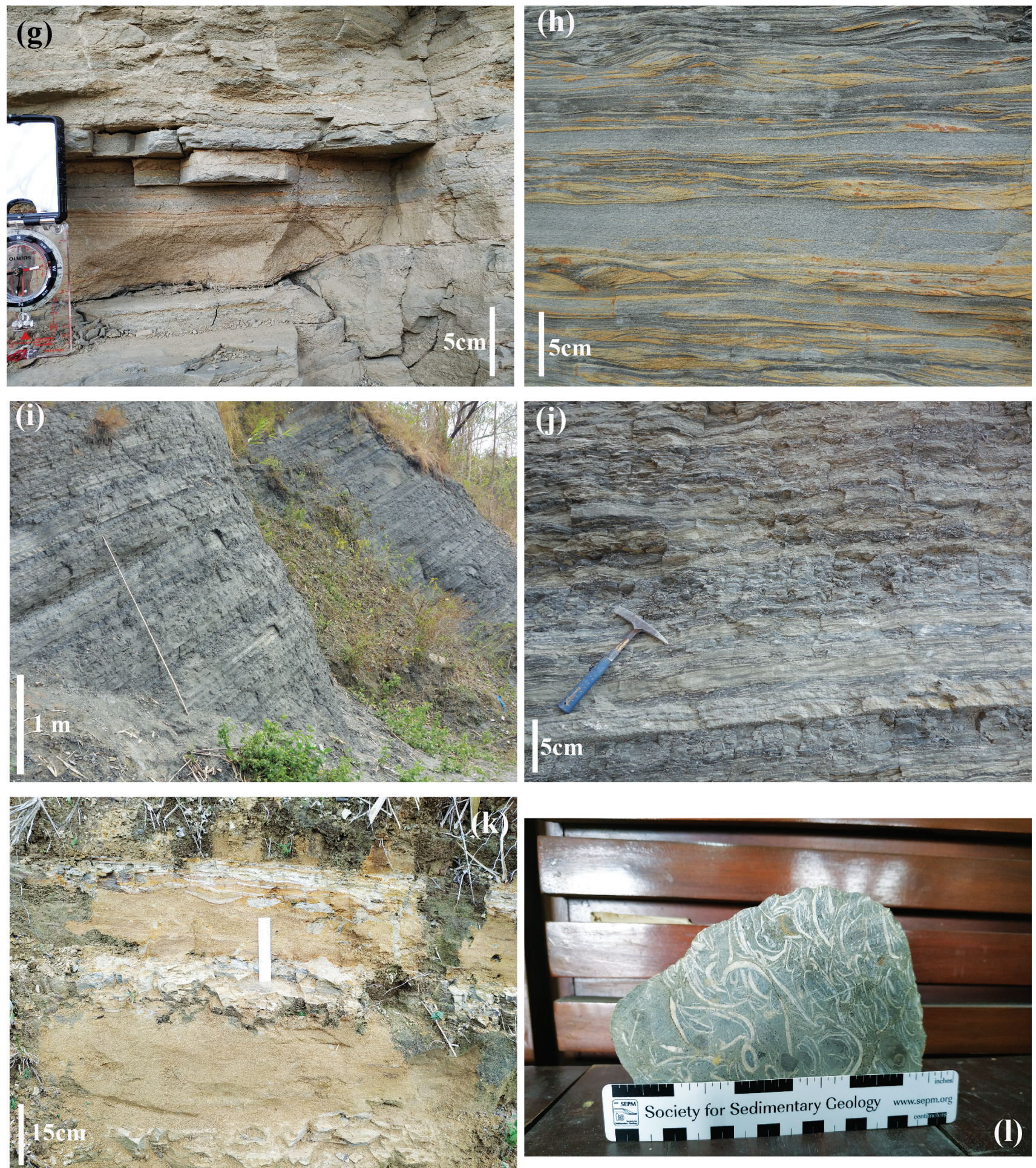

Fig. 3 (cont.): (g) Parallel laminated sandstone siltstone facies with laminated to massive mudstone within the Boka Bil Formation with VTB at Kanapara section; (h) Parallel, ripple to lenticular laminated sandstone interbedded with parallel to wavy laminated shale. The lee and fore sets of ripple and lenticules in opposite directions indicate bidirectional paleo flow of tidal environment during deposition; (i) Lateral continuation of MBU in Bus stand section contains about $80 \%$ shale alternated with sandstone-siltstone facies; (j) Calcareous massive fine-grained sand body in the MBM (bottom in the picture) and ripple to lenticular laminated sandstone-siltstone alternate with laminated, wavy laminated to massive shale. Contain shale and sandstone-siltstone varies with depth; (k) Mud and sand-rich lithologies at Kanapara section indicate a subtidal shelf facies environment. The horizontal abundance of sand with flaser bedding indicates rapid deposition of sand over the unconsolidated mud units; (I) Fossiliferous conglomerate found in the Kanapara section contain mud clast and fossils mainly pelecypods indicate substantial bed erosion at its head. 
Table 1: Lithofacies schemes for the Bhuban and Boka Bil Formations of Surma Group in the study area.

\begin{tabular}{|c|c|c|c|c|c|c|c|}
\hline $\begin{array}{l}\text { Facies } \\
\text { code }\end{array}$ & $\begin{array}{l}\text { Sub- } \\
\text { facies } \\
\text { code }\end{array}$ & Facies Title & Texture & $\begin{array}{l}\text { Sedimentary } \\
\text { Feature }\end{array}$ & Contact & Occurrence & Interpretation \\
\hline $\mathrm{Fm}$ & & Mudstone & Clay & $\begin{array}{l}\text { Massive with } \\
\text { occasionally } \\
\text { trace fossils }\end{array}$ & Gradational & $\begin{array}{l}\text { Topmost part of } \\
\text { turbidite deposits as } \\
\text { well as tidal flats. }\end{array}$ & $\begin{array}{l}\text { Product of no bed movement in } \\
\text { slack water stage between ebb } \\
\text { and flood tide and when turbidite } \\
\text { current dies out. }\end{array}$ \\
\hline \multirow[t]{2}{*}{$\mathrm{F} 1$} & $\mathrm{Flb}$ & Bluish shale & Clay & Massive & Sharp & $\begin{array}{l}\text { Shallow marine to } \\
\text { tidal flat. }\end{array}$ & $\begin{array}{l}\text { Intertidal to shallow to deep } \\
\text { marine environment }\end{array}$ \\
\hline & Flbk & Black shale & $\begin{array}{l}\text { Clay with few } \\
\text { very fine silt }\end{array}$ & Massive & Sharp & $\begin{array}{l}\text { In both below and } \\
\text { above CCD and } \\
\text { abyssal plain }\end{array}$ & $\begin{array}{l}\text { Distal lobe basin plain/deep } \\
\text { marine environment }\end{array}$ \\
\hline Fw & & $\begin{array}{l}\text { Very fine silty } \\
\text { shale to shale }\end{array}$ & Clay with silt & $\begin{array}{l}\text { Massive with } \\
\text { occasionally silt } \\
\text { trace }\end{array}$ & Sharp & $\begin{array}{l}\text { Shallow marine to } \\
\text { tidal flat and/or deep } \\
\text { marine }\end{array}$ & $\begin{array}{l}\text { Intertidal to shallow marine } \\
\text { environment overlapping lenses or } \\
\text { ripples; as overlying mud drapes } \\
\text { in distal turbidites in distal lobe } \\
\text { basin plain environment. }\end{array}$ \\
\hline Sll & & $\begin{array}{l}\text { Lenticular } \\
\text { laminated } \\
\text { sandstone- } \\
\text { siltstone-shale }\end{array}$ & $\begin{array}{l}\text { Very fine sand } \\
\text { to silt within } \\
\text { clay }\end{array}$ & $\begin{array}{l}\text { Lenticular } \\
\text { lamination }\end{array}$ & Sharp & $\begin{array}{l}\text { Starved ripple in } \\
\text { a mud dominated } \\
\text { environment and/or } \\
\text { deep marine }\end{array}$ & $\begin{array}{l}\text { Product of ripple movement } \\
\text { alternating with mud deposition of } \\
\text { tidal flat environment; as overlying } \\
\text { mud drapes in distal turbidites in } \\
\text { distal fan environment. }\end{array}$ \\
\hline $\mathrm{Sf}$ & & $\begin{array}{l}\text { Flaser } \\
\text { laminated } \\
\text { sandstone- } \\
\text { siltstone }\end{array}$ & $\begin{array}{l}\text { Very fine- } \\
\text { grained sand to } \\
\text { silt with clay }\end{array}$ & Lamination & Sharp & $\begin{array}{l}\text { Clay as flaser, mostly } \\
\text { within the trough of } \\
\text { ripple }\end{array}$ & $\begin{array}{l}\text { Deposition in standstill phase } \\
\text { and current activity in tidal } \\
\text { environment. }\end{array}$ \\
\hline $\mathrm{S} 1$ & & $\begin{array}{l}\text { Horizontal } \\
\text { Laminated } \\
\text { sandstone- } \\
\text { siltstone }\end{array}$ & $\begin{array}{l}\text { Medium to fine } \\
\text { sand, silt, and } \\
\text { clay }\end{array}$ & Lamination & Sharp & $\begin{array}{l}\text { Plane bed in bar } \\
\text { tops intertidal flat/ } \\
\text { parallel laminated in } \\
\text { diminished turbidity } \\
\text { current (Td) }\end{array}$ & $\begin{array}{l}\text { Lower flow regime plane bed in } \\
\text { marine environment as tidal flat / } \\
\text { turbidite Td division }\end{array}$ \\
\hline $\mathrm{Sr}$ & & $\begin{array}{l}\text { Ripple cross- } \\
\text { laminated } \\
\text { sandstone- } \\
\text { siltstone } \\
\text { current } \\
\text { generated }\end{array}$ & Fine sand to silt & $\begin{array}{l}\text { Ripple } \\
\text { lamination } \\
\text { current/ wave } \\
\text { generated }\end{array}$ & Sharp & $\begin{array}{l}\text { Small scale } 2 \text {-d and } \\
\text { 3-d ripple }\end{array}$ & $\begin{array}{l}\text { In abandoned part of channel, } \\
\text { shallow and crevasse channel, tidal } \\
\text { flat at shallow water environment; } \\
\text { filling up Tc in levee or shallow } \\
\text { lobe of the submarine fan. }\end{array}$ \\
\hline $\mathrm{Sp}$ & & $\begin{array}{l}\text { Planar cross } \\
\text { stratified } \\
\text { sandstone }\end{array}$ & $\begin{array}{l}\text { Medium to fine- } \\
\text { grained sand } \\
\text { with occasional } \\
\text { silt. }\end{array}$ & $\begin{array}{l}\text { Planar cross- } \\
\text { stratification. }\end{array}$ & sharp & $\begin{array}{l}\text { Deposition in the } \\
\text { shallower part } \\
\text { of tidal channel } \\
\text { sandstone. }\end{array}$ & $\begin{array}{l}\text { Product of migration of sub- } \\
\text { aqueous 2-D large ripple in } \\
\text { shallow water tidal environment. }\end{array}$ \\
\hline ST & & $\begin{array}{l}\text { Turbidite } \\
\text { sandstone }\end{array}$ & $\begin{array}{l}\text { Medium to fine } \\
\text { sand }\end{array}$ & $\begin{array}{l}\text { Graded bedding } \\
(\mathrm{Ta}), \text { flat } \\
\text { bedding }(\mathrm{Tb}), \\
\text { ripple }(\mathrm{Tc})- \\
\text { and parallel } \\
\text { lamination(Td) }\end{array}$ & $\begin{array}{l}\text { Gradational } \\
\text { to erosive } \\
\text { and sharp }\end{array}$ & $\begin{array}{l}\text { Channel fill, shallow } \\
\text { scour fill, and flat } \\
\text { based turbidites }\end{array}$ & $\begin{array}{l}\text { Complete/incomplete turbidite } \\
\text { of Bouma sequence, mostly in } \\
\text { distributary channel fill in the } \\
\text { submarine fan }\end{array}$ \\
\hline $\mathrm{Sm}$ & & $\begin{array}{l}\text { Massive } \\
\text { sandstone }\end{array}$ & $\begin{array}{l}\text { Medium to fine } \\
\text { sand }\end{array}$ & $\begin{array}{l}\text { No bedding } \\
\text { or faint dish } \\
\text { structure. }\end{array}$ & $\begin{array}{l}\text { erosive to } \\
\text { sharp }\end{array}$ & $\begin{array}{l}\text { Channel fill shallow } \\
\text { scour fill curved } \\
\text { based turbidites }\end{array}$ & $\begin{array}{l}\text { Channel of massive sandstone in } \\
\text { submarine fan environment. }\end{array}$ \\
\hline Gms & & $\begin{array}{l}\text { Matrix } \\
\text { supported } \\
\text { conglomerate }\end{array}$ & $\begin{array}{l}\text { Coarse to fine } \\
\text { sand with } \\
\text { occasional } \\
\text { pebble }\end{array}$ & $\begin{array}{l}\text { Matrix } \\
\text { supported } \\
\text { sandstone. } \\
\text { Occasionally } \\
\text { fossil present }\end{array}$ & $\begin{array}{l}\text { erosive to } \\
\text { sharp }\end{array}$ & $\begin{array}{l}\text { High-velocity } \\
\text { turbidity current }\end{array}$ & $\begin{array}{l}\text { Product of current activity } \\
\text { in turbidity channels in the } \\
\text { proximal submarine fan below the } \\
\text { continental slope. }\end{array}$ \\
\hline $\mathrm{Gm}$ & & $\begin{array}{l}\text { Clast } \\
\text { supported } \\
\text { conglomerate }\end{array}$ & $\begin{array}{l}\text { Pebble to } \\
\text { siltstone }\end{array}$ & $\begin{array}{l}\text { Clast supported } \\
\text { sandstone. } \\
\text { Occasionally } \\
\text { fossil present }\end{array}$ & $\begin{array}{l}\text { erosive to } \\
\text { sharp }\end{array}$ & $\begin{array}{l}\text { High-velocity } \\
\text { turbidity current }\end{array}$ & $\begin{array}{l}\text { Product of current activity } \\
\text { in turbidity channels in the } \\
\text { proximal submarine fan below the } \\
\text { continental slope. }\end{array}$ \\
\hline
\end{tabular}

\section{Planar Cross-stratified Sandstone Facies (Sp)}

The thickness of co-sets of planar cross-strata gradually becomes smaller upward in the litho-succession. The planar set ranges in height from few centimeters to few decimeters. The large scale planar cross-stratified sandstones are found in the Boka Bil Formation of the Kanapara section and Sailapropat section. The planar set ranges in height from one to two meters. The small scale planar cross-stratified facies occur in the Boka Bil Formation of the Nilachol section. The planar set ranges in height from few centimeters to a decimeter (Fig. 3j).

A morphological change of crinkle lamination, angular foreset, tangential foreset, concave foreset, 
and sigmoidal foreset with accompanying gradual increase of grain size and corresponding angle of foreset. The subsequent fall of grain size and angle of foreset is well recognized with in the large and small planer cross strata in the study area. In general, the thickness of forests varies from 10 to $45 \mathrm{~cm}$ with $5^{\circ}$ to $9^{\circ}$ dip noted during the study. Mud drapes and mud balls are frequently present along the foreset of the planer cross strata.

These occur as shallow channel fills or alternately with parallel laminated blue shallow marine shale. Yellowish brown to yellowish gray colored sandstone indicates their origin in shallow to moderately deep water oxygenated conditions, whereas the bluish gray-colored shale supports their shallow marine origin. Morphological changes of foreset along with the grain size and foreset dip suggest acceleration flowed by deceleration of flow condition (Terwindt, 1981). Mud drapes and mud balls suggest slack water deposits when flow conditions was very slow or null (De Raaf et al., 1977). This type of waxing and waning of flow condition with very slow or null conditions strongly suggest tidal action within the deposit of Sp facies (Reineck and Singh, 1980; Roy et. al., 2007b; Hossain et. al., 2008).

\section{Ripple Laminated Sandstone-siltstone Facies (Sr)}

Ripple laminated and ripple cross-laminated sandstone-siltstone lithofacies consists of grayishwhite to grayish-brown colored, medium to finegrained sandstone-siltstone. This facies is also a dominant lithofacies in the study area. Ripples are asymmetric in profiles and sinuous crested, mostly languid and lunate in nature. The lithofacies ranges in thickness varying from a few $\mathrm{cm}$ to $1 \mathrm{~m}$ (Figs. $3 \mathrm{~h}$ and $\mathrm{J}$ )

These ripples are 3-dimensional in forms, mostly languid and lunate with sinuous crest lines having ripple symmetry indices (RSI) in the range of 0.95 to 2.57 and ripple indices (RI) in the range of 9 to 22. The internal architectures of fore sets of some ripples are simple concerning wave-formed ripples, where paleocurrent is in a single direction. Based on RI and RSI these ripples are now classed as mixed in origin. The ripple index (RI) value of 2 to 22 and ripple symmetry index (RSI) value of 1.20 to 5.60 with internal unidirectional foreset suggest that these ripples might have produced by the action of wave (symmetrical) or current (asymmetrical) in shallow or moderately deepwater environment (Boersma, 1969; De Raaf et al., 1977). The ripple within black shales is distal turbidites (Walker, 1984). In some sections, the convolute ripples are observed, which might have caused by seismic shock or slope failure (Bhattacharyya and Chakroborty, 2000).

\section{Flaser Laminated Sandstone-Siltstone Facies (Sf)}

Flaser laminated sandstone-shale facies are less abundant in the study area. Ripple bedding in which mud streaks are preserved completely in the trough and partly on the crest of the ripple known as flaser lamination (Reineck and Singh, 1980). It is constituted mainly by yellowish-brown to light yellow color fine sandstone to siltstone with subordinate light gray colored clay shingles and mud drapes which are preserved along the troughs of ripples (Fig. 3k). The overall thickness of these facies ranges from 0.1 to $1 \mathrm{~m}$.

Flaser laminated sandstone-siltstone facies (Sf) is the product of an environment where peak flow direction for deposition of coarser sand-silt particle alternates with slack water stage for the deposition of mud/ clay particles in a periodic fashion. Such condition is usually observed in tidal environment (Reineck and Singh, 1980; Terwindt, 1981; De Raaf et al., 1977, Roy et al., 2007b).

\section{Horizontal Laminated Sandstone-Siltstone Facies (SI)}

Horizontally laminated sandstone siltstone facies is composed of fine to very fine sandstone and siltstone and occasionally silty-shale, which are gray to light bluish-gray in color (Figs. 3e, h, and J). This lithofacies commonly occurs over the $\mathrm{Sr}$ facies. Lamination is parallel to sub-parallel with very low degree of inclination, i.e., nearly flat without any signature of parting lineation. Convolutions are present in these facies and are composed of yellowish to light yellowish-gray color very fine sand to silt, occasionally clay-rich, which are $1 \mathrm{~cm}$ to $12 \mathrm{~cm}$ in thickness.

The facies without parting lineation suggests their origin either from suspension or slow-moving current under lower flow regime conditions (Harms et al., 1982). Parallel laminations are the product of deposition of suspension clouds due to a decrease in the turbulence of fluctuation in current velocity (Reineck and Singh, 1980). The parallel lamination may be the product of turbidite channel deposits when flow dies out (Kumar and Sanders, 1974). Convolute laminated sub facies develops from deformation of the structure either due to rapid deposition or liquefaction of underlain sediments (Alam, 1990). This may also represent a varied depositional environment like flood plain of the fluvial environment (e.g., McKee et al., 1967 and Alam, 1992); estuary (e.g., Dalrymple et al., 1992; Cooper, 1993; Roy et al., 2007b; Hossain et al., 2008; Gingras et al., 2012); tidal flat (e.g., Biswas, 1961; Davis, 1978) and the distal lobe of a submarine fan (e.g., Pickering and Hiscolt, 1989; Hesse, 1975; Roy et al., 2007a; Covault, 2011). 


\section{Lenticularlaminated Sandstone-siltstone-siltyshale Facies (SII)}

The facies is constituted by yellowish gray to grayish-white colored very fine sandstone to siltstone embedded within shale or mudstone. Virtually these lenses are ripples, mostly current generated and lenses are a few $\mathrm{mm}$ to few $\mathrm{cm}$ thick and shale-mudstone layers surround these lenses (Figs. 3e and j). However, some are wavy in appearance. This facies is observed in the shale/mudstone dominated part of heterolithic litho-succession. It is, in fact, made up of sand lenses within the blue/black shale alternating with mud layer repeatedly over a longer distance in space and time. The facies is occasionally highly bioturbated.

Current or wave action depositing very fine sand to silt alternating with slack water condition when mud is deposited and formed lenticular lamination sandstone siltstone-silty shale facies (S1l; Reineck and Singh, 1980). Foreset laminae of current ripple or wavy ripple made these sand-silt layers. It also indicates the absence of abundant supply of coarser clastic to form a continuous lamination. Thus, the main environment of the formation of the facies is subtidal to intertidal zone (Reineck, 1960; Reineck and Wunderlich, 1968) and deep sea. The lenses also indicate distal turbidite deposits within an anoxic pelagic environment (Reading, 1996; Shanmugam, 2008; 2016; Wetzel and Uchman, 2012).

\section{Wavy Laminated Very Fine Silty Shale to Shale (Fw)}

This facies is constituted by shale having wavy laminated sedimentary structures and dark gray to blackish gray in color (Figs. 3e, h, and J). The bed contact is more or less sharp and it normally overlies ripple to lenticular laminated sandstone-siltstone facies.

The forward and backward motion of the wave in fined grained sandy silty sub-strata forms ripple and lenses and wavy laminations are produced by the draping of the underlying ripples or lenses. This facies indicates slack water conditions in which mud can also deposit along with sand-silt, which is commonly observed in tidal environments (Boggs, 2001). In submarine distal fan environment, when distal turbidites as ripples and lenses are draped by pelagic or hemipelagic mud, this facies can be generated (Boggs, 2001; Shanguman, 2008; 2003; Roy et. al., 2007a; Daidu et al., 2013).

\section{Laminated Shale Facies (FI)}

This facies includes two sub facies, which are black shale (Flbk) and bluish shale (Flb). Flb sub facies comprise gray to blue parallel laminated shale as exposed in the Boka Bil Formation of the study area (Fig. 3h). Trace fossils with leaf impression and root traces (mostly calcareous) are present within these facies. Thickness varies from $0.2-1.0 \mathrm{~cm}$. Flbk is exposed most abundantly and covers about 80 percent of the MBM (Fig. 3i). Moreover, at places, spheroidal weathered shale is common in the Bhuban Formation. At few locations fossil impressions including escape traces are present. Within these sub facies, a few number of shallow preserved channels of 2 to $4 \mathrm{~m}$ wide and 0.05 to $1 \mathrm{~m}$ deep have been recorded. These smallscale scours are filled by very fine-grained sandstone to siltstone. Calcareous concretionary bodies are locally present, most of which are spheroidal, ellipsoidal, and disc-shaped (Fig. 3j).

Bluish gray (Flb) shale indicates clam and quiet environment where flow velocity was very sluggish, it may represent suspension fallout estuarine over the bank, a tidal flat, marshy area attached to an estuary, and vertical accretion of channel fill of estuarine environment (Dalrymple et al., 1992; Tirsgaard, 1993; Roy et. al., 2007b; Gingras et al., 2012). This may be deposited of slack water deposition between the ebb and flood tide in the intertidal environment; particularly in the mud-rich tidal flat (Reineck and Singh, 1980; Daidu et al., 2013).

The calcareous, as well as non-calcareous natures of black shale, suggest that it was deposited both below and above carbonate composition depth (CCD), a depth below which carbonates are completely dissolved (Hesse, 1975). This shale is in fact pelagichemipelagic deposit in a deep-sea environment, particularly in bathyal and abyssal plain (Bouma, 1962; Hesse, 1975; Mutti, 1977; Wetzel and Uchman, 2012). The interbedded very fine grain clastic sediment of these facies are regarded as distal turbidites. It denotes a calm and quiet condition which is a distal submarine fan environment.

\section{Massive Mudstone Facies (Fm)}

A minor constituent of gray to bluish-gray-colored massive mudstone facies found in the sediments. Normally it is found in the uppermost part of the turbidite sandstone facies and tidal mudflat deposits. It lacks any sedimentary structure, although occasionally roots traces, leaf imprint, bio-churned with vertical and inclined trace fossils are present. It occurs mostly in the uppermost part of the whole litho-succession (Figs. 3e and $\mathrm{j}$ ).

It indicates calm and quiet environments where the flow velocity is practically nill. It may represent suspension fallout as mud blanket (Te) when turbidity current dies out in distal fan environment below continental slope (Bouma, 1962; Hesse, 1975; Roy et. al., 2006, 2007a). These facies may be generated as slack water conditions in tide-dominated environments specifically in tidal flats (Dalrymple et. al., 1992; Hossain et al., 2008; Roy et. al., 2007b; Daidu et al., 2013). 

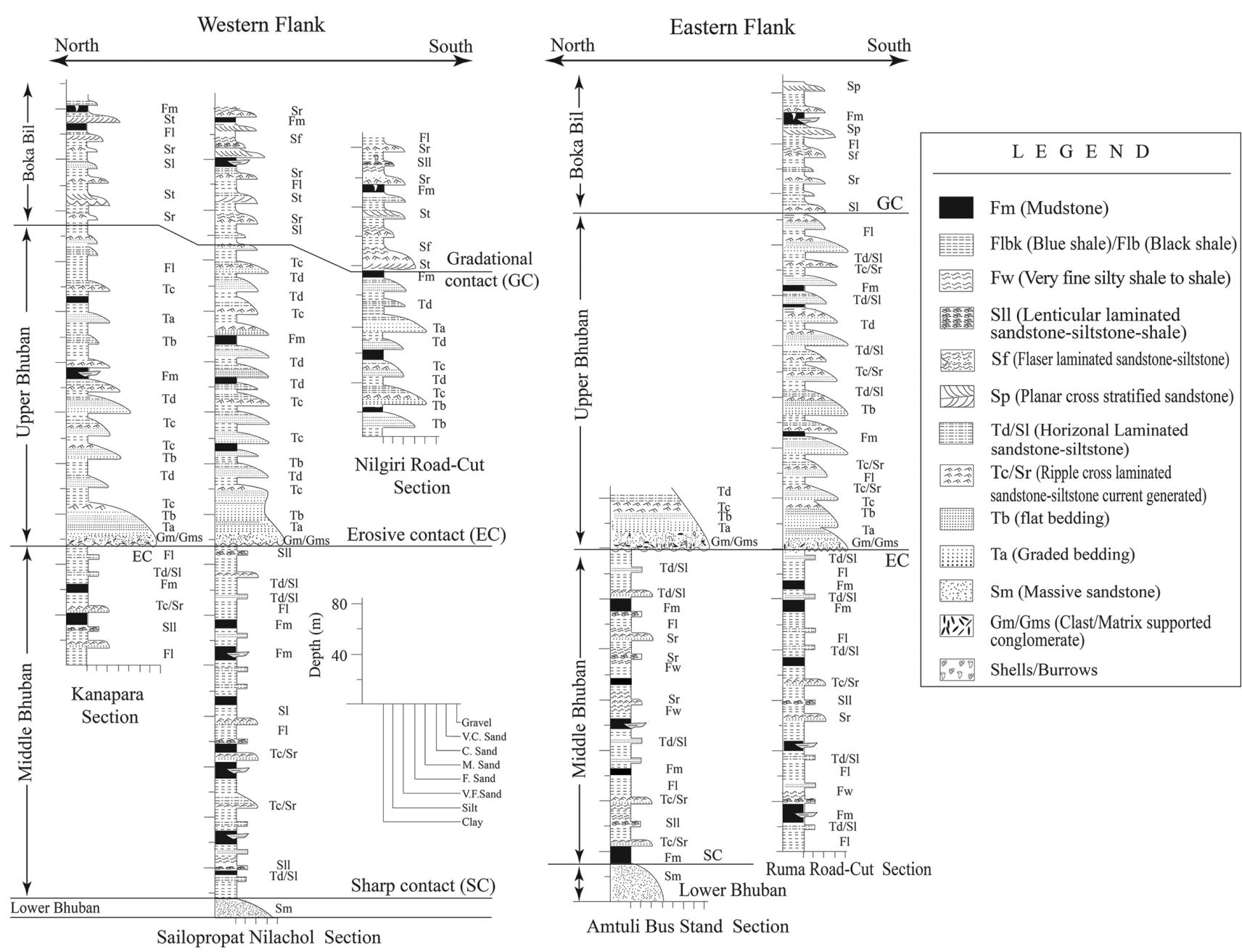

Fig. 4: Summarized lithology of exposed rock sections in eastern and western flank from the Bandarban anticline showing grain size, sedimentary structure with contact.

\section{FACIES ASSOCIATION}

Facies association (FA) is a group of lithofacies that occur together and are considered to be genetically or environmentally related, thereby making more information than a facies in isolation from its neighbors (Reading, 1996). So, the analysis of facies is thus the most fundamental to all environmental interpretations and paleogeographic reconstruction (Miall, 1986; 1990; Boggs, 2001). Based on the grain size, sedimentary structures, inference, and genesis of individual facies, the facies can be grouped into three facies associations (Fig. 5) within the studied area are as followed.

\section{FA-A (turbidite generated)}

This facies association is well exposed in more or less all the studied litho-successions of the Bhuban Formation at the Bandarban anticline. This facies association is constituted by the facies $\mathrm{Gm}, \mathrm{Gms}$, Sm, and ST (Fig. 5a). The lower contact of this facies association is erosive, occasionally the upper contact is gradational with steel gray shale. This facies association is normally characterized from base to top by graded bedding $(\mathrm{Ta})$, flat bedding $(\mathrm{Tb})$, ripple cross lamination $(\mathrm{Tc})$, faint parallel lamination $(\mathrm{Td})$, and finally massive mud (Te) in the uppermost portion of the association when complete classical turbidites sequence is present; otherwise incomplete Bouma sequence may have any form of presence like $\mathrm{T}(\mathrm{abc})$, $\mathrm{T}(\mathrm{bce}), \mathrm{T}(\mathrm{ace})$ and so on (Fig. 3f). Grain size varies from medium grain sandstone to siltstone and the color of the facies association is normally bluish gray to brownish gray. Facies $\mathrm{Gm}, \mathrm{Gms}$ and $\mathrm{Sm}$ are locally present at the basal part of this association (Fig. 3a).

Clast supported conglomerate $(\mathrm{Gm})$ and matrixsupported conglomerate $(\mathrm{Gms})$ are indicating of the deposition in trunk turbidity channels within the submarine mid fan channelized lobe setup by gravity flow or mass flow (Fig. 6). The Sm facies is denoted by quick deposition in mid fan channelized and nonchannelized lobe of turbidite sediment in current in proximal to medial fan setup (Shanguman, 2003; 2008; Zakaria et al., 2013).

\section{FA-B (outer fan distal lobe basin plain)}

The constituent facies of this association are mainly ripple laminated sandstone-siltstone facies ( $\mathrm{Sr} /$ Tc), horizontal laminated sandstone-siltstone- silty 
claystone (Sl/Td), lenticular laminated siltstonesandstone (S1l), wavy laminated shale $(\mathrm{Fw})$, and parallel laminated silty shale (Fl) which is mainly black shale with few sporadic Ta, Tb, and Tc (Fig. 5 b). Monotonous shale with a regular arrangement of hemipelagic sediments indicates the distal fan basin plain sedimentation and pelagic shale/ mudstone with some silty stringers indicates the submarine basin plain facies association (Wetzel and Uchman, 2012; Zakaria et al., 2013). The shale/ mudstone are mostly suspension fall out in submarine basin plain as hemipelagic and pelagic sediments, whereas facies Sll, Sl, Ta, Tb and Tc are distal turbidities carried by turbidity current from landward source area in distal paleogeographic setup (Fig. 3e, $\mathrm{i}$ and j).

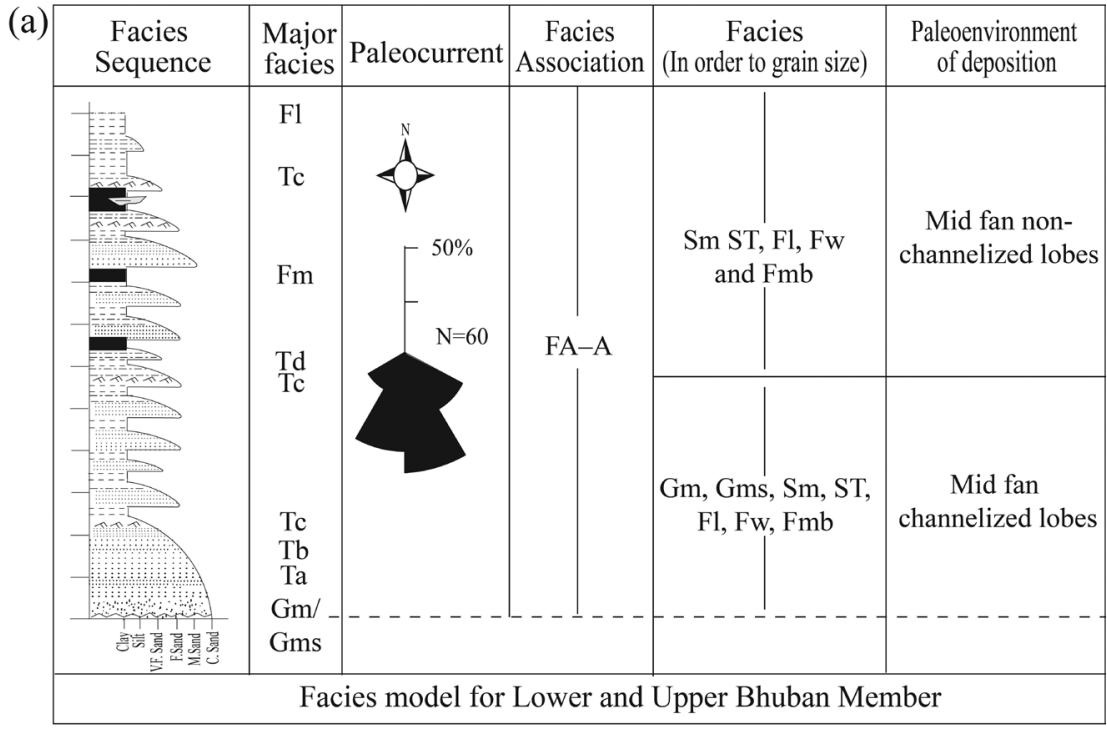

(b)
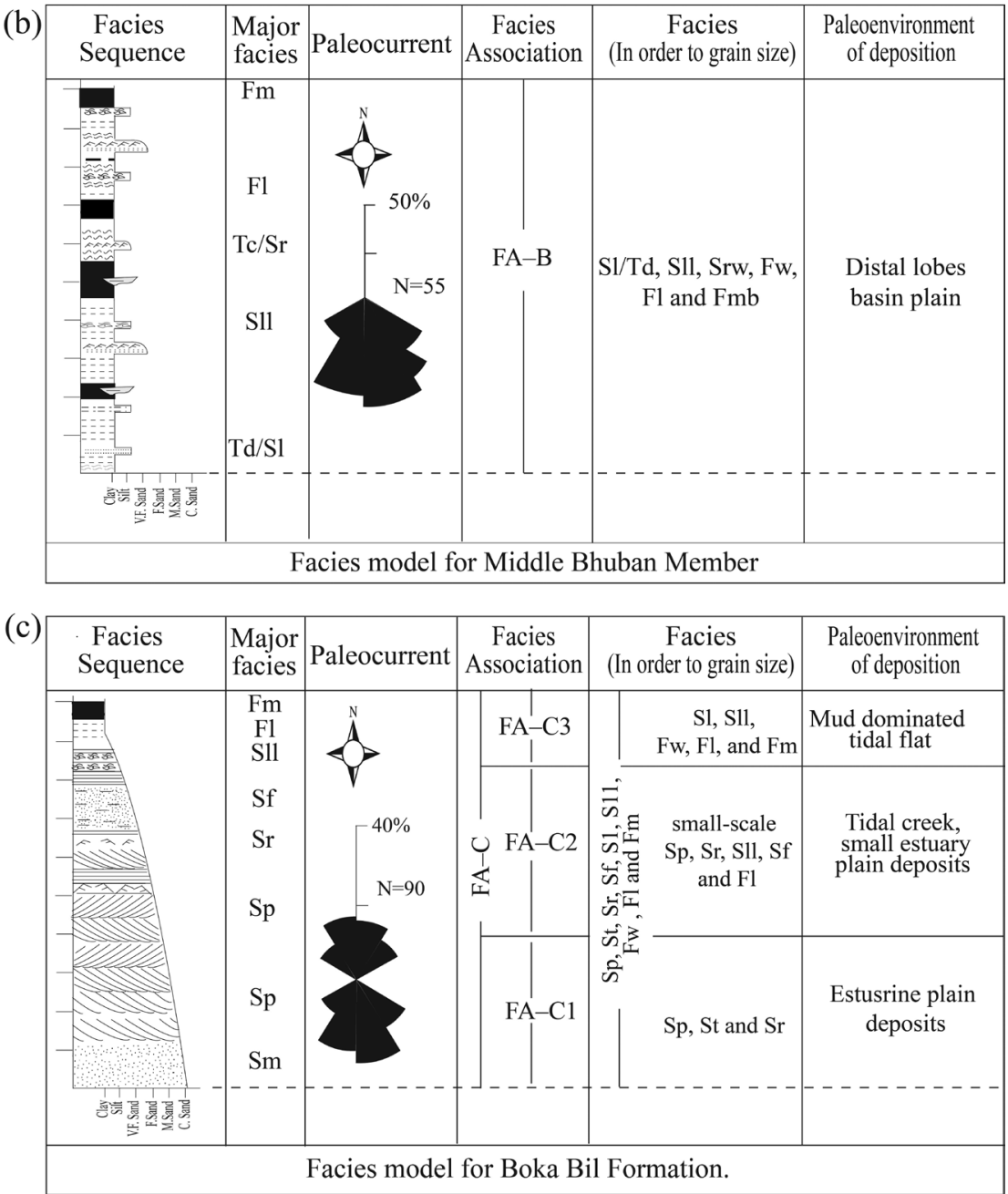

Fig. 5: Facies model, facies sequence, paleocurrent, facies association, and paleoenvironment of (a) LBM and UMB; (b) MBM; and (c) Boka Bil Formation of the study area. 


\section{FA-C (tide-influenced)}

Tide-influenced facies association is generated by the tidal action and is restricted to coastal paleogeographic setup (Fig. 5c). The strong tide was observed in estuaries and tidal rivers and the weak tide was observed within the tidal creeks and tidal flat. Deposition from very weak tide and standstill conditions of tidal deposition is restricted within the mud-dominated tidal flat. This facies association has got three variants which are described below:

\section{FA-C1 (estuarine sub-facies association)}

This medium to fine-grained facies association is restricted to strong tidal process in channels (large or small). Sediment thickness is not large and it comprises facies of large scale $\mathrm{Sp}, \mathrm{Sr}$, and $\mathrm{Sl}$ where $\mathrm{Sp}$ is most dominant. In this sub-facies association, fluctuation of water velocity both in magnitude and direction as indicated by bedform height/foreset thickness and direction up and down local paleoslope as marked by bi-directional paleo flow and water depth in periodic order is regarded as tides in response to attractions of the moon-earth-sun system. High-frequency tidal cycles include semidiurnal, diurnal, mixed, fortnight, and monthly cycles. This type of tidal cyclicity may be determined from the lateral succession of planar cross-stratification of $\mathrm{Sp}$ and $\mathrm{Sr}$ facies with mud drape on fore sets (Terwindt, 1981; Roy et. al., 2007b; Hossain et. al., 2008; Gingras et al., 2012).

\section{FA-C2 (tide-influenced sub-facies association)}

Vertical accreted tidal bundle (VTB), consisting of alternations of comparatively thicker lamina of sandstone-siltstone layers with apparently sharp contact and thinner shale layer are sometimes visible within this sub-facies association particularly in the Sailoprapat-Nilachol section (Figs. $3 g$ and $5 \mathrm{c}$ ). According to Shii (1991), thick sand/silt rich layers with facies small-scale $\mathrm{Sp}, \mathrm{Sr}, \mathrm{Sf}$, Sll, represent spring tide periods (7-8 days), and thin mud rich layers with facies Flw, Flg and Fm may indicate neep tidal periods (8-7 days). Paleocurrents show bipolarity.

\section{FA-C3 (mud dominated tidal flat sub-facies association)}

This facies association comprises about $10-25 \%$ of parallel laminated sandstone-siltstone facies (S1), lenticular laminated sandstone-siltstone facies (S1l), and $75 \%-90 \%$ of parallel to wavy laminated gray shale facies $(\mathrm{Fw})$ and unstructured mud facies $(\mathrm{Fm})$ (Fig. 5c). The facies, sub-facies association, and paleocurrent pattern of this facies association suggest that the deposition was restricted to estuaries and coastal shallow marine to intertidal flat environments (De Reaf et al., 1977; Reineck and Singh, 1980; Terwindt, 1981; Dalrymple, 1992; Daidu et al., 2013).

\section{FACIES MODEL}

A facies model can be viewed by the sequential relationship of facies in a stratigraphic sense. The construction and use of facies models continue to be one of the most active areas in general field of stratigraphy. The first facies model is for deposits formed by turbidity currents at the base of continental slope within the upper part of the channelized to nonchannelized submarine fan, which is much common in litho-succession of the UBM and also observed in part of the LBM (Fig. 5a). This facies model is formed by huge sediment deposits through turbidity channels during the upliftment of the Himalaya. The progradation and regression phases of submarine fan development are observed in the litho succession of the different sections of the study area. The thickness of the sand deposits varied from 1 to 12 $\mathrm{m}$ and massive to parallel mud facies overlayed the sequence.

The second facies model is for outer fan distal lobe basin plain deposits, mostly suspension fallout as pelagic and hemipelagic (Fig. 5b). Distal turbidites like Sr, Sll, Sl (Td), and/or few sporadic Ta, Tb, and Tc are not uncommon within it. This is the most persistent facies model within the Bhuban Formation, especially the MBM. The thickness of the laminae varied up to few $\mathrm{mm}$ to $15 \mathrm{~cm}$ and hard calcareous sandstone bodies found within these facies (Figs. 3e and J). The third facies model that characterizes the Boka Bil formation is constituted by the deposits produced in the marginal marine setup of the estuary, tidal river, tidal creek, and tidal flat environment where tide is the dominant agent which is recognized by reversibility of paleo flow directions in the litho-column (Fig. 5c). The channel width was $19 \mathrm{~m}$ and depth 1-3.5 m noted during field investigation.

\section{ENVIRONMENT OF DEPOSITION}

Twelve lithofacies constitute both the Bhuban and Boka Bil Formations. Massive sandstone (Sm) and turbidite sandstone (ST) inter-bedded with minor amount of black shale that form FA-A constituting the UBM, where Gm and Gms facies contribute the basal part (Fig. 3a). The Middle Bhuban Member is constituted mainly by the FA-B and the upper part of the LBM mainly massive calcareous sandstone of FA-A (Figs. 3b and c). In Boka Bil Formation lithofacies Sp, Sr, Sf, S1, S11, Fw, Fl, and Fm are the main constituents that form the $\mathrm{FA}-\mathrm{C}$ with subfacies $\mathrm{FA}-\mathrm{C} 1, \mathrm{FA}-\mathrm{C} 2$ and $\mathrm{FA}-\mathrm{C} 3$.

The incomplete classical turbidite sequences are represented by $\mathrm{T}(\mathrm{bc}), \mathrm{T}(\mathrm{bcde})$, and $\mathrm{T}(\mathrm{ab}), \mathrm{T}(\mathrm{bc})$, $\mathrm{T}(\mathrm{cd}), \mathrm{T}(\mathrm{cde}), \mathrm{Ta}, \mathrm{Tb}, \mathrm{T}(\mathrm{abce})$, and $\mathrm{T}$ (abde), of which $\mathrm{T}(\mathrm{ac}), \mathrm{T}(\mathrm{bd})$ and $\mathrm{T}(\mathrm{abe})$ are most common and $\mathrm{T}(\mathrm{abe})$ and $\mathrm{T}(\mathrm{ac})$ sequences are rare. The $\mathrm{Gm}, \mathrm{Gms}, \mathrm{Sm}$ 
facies represents turbidity channel in the inner part of the proximal submarine fan (Figs. 3a, d and 4). The less distinct facies like Sp, Sr, Sl, and Sll; and/or few sporadic $\mathrm{Ta}, \mathrm{Tb}$, and $\mathrm{Tc}$ in shale-dominated outer fan distal lobe marine basin plain facies association indicates turbidity generated rhythms in the deep marine environment (Shanmugam, 1980; 2016). The black-colored, paper-thin laminated shale indicates a reducing calm and quiet environment i.e. the unit was deposited in the outer fan distal lobe deep marine environment (Stow, 1986; Roy et al., 2006; 2007a). The $\mathrm{Sm}$ facies denotes a channel in proximal to medial submarine fan set up. The facies ST (complete or incomplete) along with Sr, Sl, and Sll indicate their deposition by a turbidity current in a more distant medial to distal fan environment (Stow, 1986; Shanmugam, 1980; Zakaria et al., 2013; Roy et al., 2006; Covault, 2011).

All these pieces of information suggested that the Bhuban Formation in the study area was deposited with progression and regression phases of submarine fan development below the continental slope, which were alternated by shale due to change flow regime or relative sea-level change in the Miocene (Haq et al., 1987) and tectonic activity with short temporal and spatial sense (Najmann et al., 2012). The massive calcareous sandstone of the LBM changed to blackcolored, paper-thin laminated shale facies of the MBM indicate the relative sea level rise due to tectonic subduction of the Indian Plate beneath the Eurasian Plate. Monsoon climate effect relatively week before 13-14 Ma and the intensity of South Asian Monsoon gradually increased after that (Clift and Plumb, 2008; Betzler et al., 2018). Huge sediment was carried through the ancient fluvial system by unroofing the Himalaya. The uplift of the Himalaya and the Tibetan Plateau influenced the monsoon, the strength of the monsoon influenced the erosion of the Himalaya. A huge amount of eroded sediment carried in submerged river delta in the Bay of Bengal and the weathered rocks carried by upstream peaks at 5-13 Ma in the stratigraphic record suggesting that the monsoon was strong during this period (Clift and Plumb, 2008). Upliftment of the Himalaya subsequently increases monsoonal activity increased the sedimentation rate during the deposition of the UBM sandstone. The presence of mud clast at the base of the UBM indicates it likely deposited near the continental slope of the proximal fan and also eroded pre-existing mud deposits of the MBM (Shanmugam, 2016; Shan et al., 2020).

The Boka Bil Formation deposited under coastal/ marginal marine environment which is represented by the presence of $\mathrm{Sp}, \mathrm{Sr}, \mathrm{Sf}, \mathrm{S} 1, \mathrm{~S} 11$, and Flb facies of $\mathrm{FA}-\mathrm{C}$ and supported by bi-directional paleo flow pattern (Figs. $3 \mathrm{~h}$ and $\mathrm{k}$ ). The influence of monsoonal activity during the late Miocene carried huge sediment from the Himalaya to the Himalaya foreland basin that dramatically shifted the prograding delta system towards the south. The oblique subduction of the Indian Plate beneath the Burmese Plate in an arctrench developed an accretionary prism and started upliftment of the area (Hossain et al., 2019). It also caused the gradual shifting of the environment from the shelf-slope deep marine to marginal shallow marine. This environment passed into the subtidalintertidal-tidal flat and estuarine plain deposits, which were caused by the regression stage of the sea during the late Miocene (Haq, et al., 1987).

\section{PALEOCURRENT AND PALEOSLOPE}

Paleocurrent and paleoslope analysis provide important information about paleogeographic setup (Potter and Pettijohn, 1977; Pettijohn, 1984; Brombley, 1991; Maill, 1991; 1993). A total of 205 measurements were used to analyze the paleocurrent rose diagram following Potter and Pettijohn (1977) (Fig. 5). In the stereo net, dominant paleo flow azimuth lying in between $150^{\circ}$ to $210^{\circ}$, and the overall paleocurrent pattern lies in the southern hemisphere. This indicates that the source area was in the north. Unidirectional flow conditions suggesting the turbidity current prevailed during the deposition of the Bhuban Formation as the depositional milieu of it was located below the continental slope in the marine environment. Bipolar-bidirectional paleo flow pattern indicates that the tidal activities dominated the depositional site of the Boka Bil Formation. A close inspection of Fig. 5 suggests that the continental slope probably E-W oriented and source areas were dispersed from $\mathrm{N} 60^{\circ} \mathrm{W}$ to $\mathrm{N} 60^{\circ} \mathrm{E}$, where the dominant one was from $\mathrm{N} 30^{\circ} \mathrm{W}$ to $\mathrm{S} 30^{\circ} \mathrm{E}$ in the Bhuban Formation. The Boka Bil Formation, the flows were spread from $\mathrm{N} 60^{\circ} \mathrm{W}$ to $\mathrm{N} 60^{\circ} \mathrm{E}$ towards $\mathrm{S} 60^{\circ} \mathrm{E}$ to $\mathrm{S} 60^{\circ} \mathrm{W}$, where the dominant one was from $\mathrm{N} 30^{\circ} \mathrm{W}$ to $\mathrm{S} 30^{\circ} \mathrm{E}$. From the present geographical point of view, the Himalaya, located in the north of the study area was the dominant source area and sediments were also sourced from the Paleogene Indo-Burmese Range of Trans-Himalaya and sediment carried by the Paleo-Brahmaputra, flowing from the east of the Shillong Plateau (Fig. 6; Najman et al., 2012; Haque and Roy, 2020). The Miocene marine fan is believed to have extended up to the Dauki Fault along the Sylhet-Meghalaya of India-Bangladesh border to the present southern limit of the Bengal Basin through the eastern folded belt and Chittagong Hill Tract's deformation did not take place before the Miocene sediment deposition (Dasgupta and Nandy, 1995; Akhter et al., 1998; Gani and Alam, 1999; Alam et al., 2003). The facies associations of channelized to nonchannelized proximal to outer fan distal lobe marine basin plain repeat and randomly occur one 


\section{(a)}

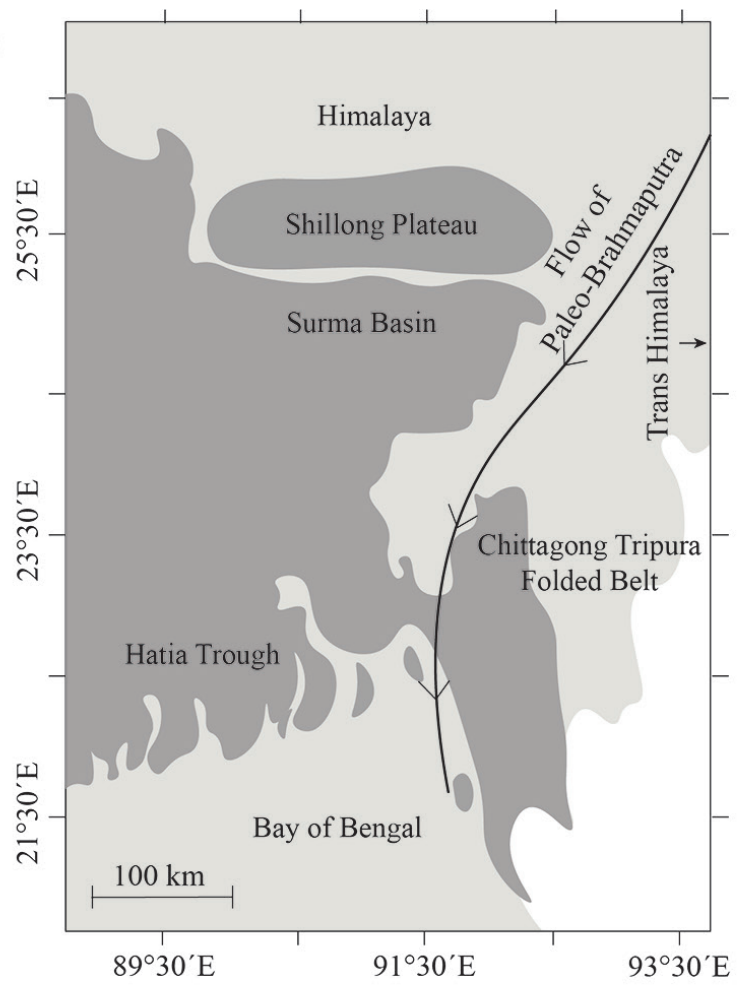

(b)

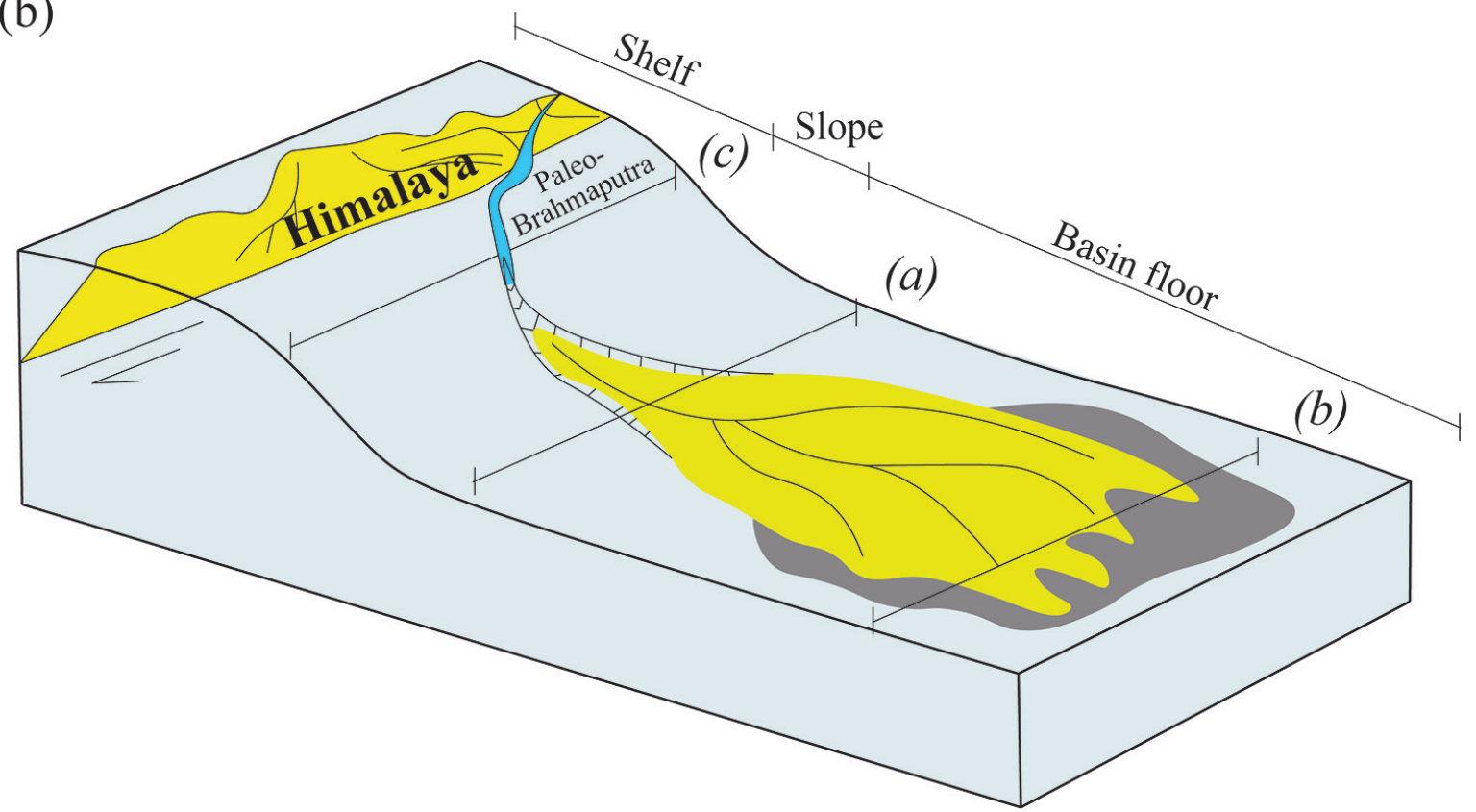

Fig. 6: (a) Paleo drainage scenario during deposition of Miocene sediment in Bengal Basin (after Najman et al., 2012); (b) Schematic depositional model for the Bhuban and Boka Bil Formations incorporate all three depositional model (a)-(c) shown in Fig. 5.

upon another in the litho-succession suggesting slope instability along basin margin formed probably by faulting along Dauki in the Meghalaya-Sylhet border and other faults of Chittagong-Tripura Folded Belt area (Gani and Alam, 1999; Alam et al., 2003; Sikder and Alam 2003). The litho-succession, paleo flow pattern and stratigraphic frame of the Boka Bil Formation suggested that the environmental setup was dominated by tide-dominated estuarine-tidal creek-tidal flat type deposition. The upliftment of the
Shillong Plateau in the Himalayan foreland occurred after $5 \mathrm{Ma}$ (Govin et al., 2018) may not significantly control the paleochannel flow and sedimentation of the Miocene Bhuban and Boka Bil Formations. The depositional system of Miocene sediment gradually changes toward the south of Himalaya from fluviodeltaic (Assam Basin) to deltaic shelf-slope basin plain environment (Hatia Trough). During the deposition of the Boka Bil Formation, the paleogeography shifted from the submarine fan/outer distal lobe marine basin 
plain to shallow marine marginal coastal environment due to regression of relative sea level, upliftment due to basin tectonics, and sediment carried from Himalaya progressively thickening toward the south at the Bengal Basin.

\section{CONCLUSIONS}

1. Lithologically, the axial zone of the Bandarban anticline consists of an alternation of gray to brownish-gray, medium to fine-grained calcareous sandstone with shale in the LBM, black shale with siltstone in the MBM, yellow to yellowish-gray coarse to medium grained sandstone-siltstone with black shale, and some conglomerate in the UBM and medium to finegrained yellow to yellowish-gray sandstone with mudstone in the Boka Bil Formation.

2. Twelve lithofacies are delineated with lithosuccession of the Surma Group. The facies are grouped into FA-A constituted by the lithofacies ST (complete and incomplete) with $\mathrm{Gm}$, Gms and Sm; FA-B made by Flbk with some Sll and $\mathrm{Sr}$; FA-C characterized by the facies $\mathrm{Sp}, \mathrm{Sr}, \mathrm{Sf}$, $\mathrm{Sl}, \mathrm{Sll}, \mathrm{Fw}, \mathrm{Flb}$ and Fm with the three sub facies association $\mathrm{FA}-\mathrm{C} 1, \mathrm{FA}-\mathrm{C} 2$ and $\mathrm{FA}-\mathrm{C} 3$.

3. Three facies models are identified, the first facies model of channelized to nonchannelized turbidite generated submarine fan (FA-A) of the UBM and also observed in upper part of the LBM. The second facies model of outer fan distal lobe basin plain deposits (FA-B), mostly suspension fallout as pelagic and hemipelagic mud of the MBM, and the tide generated (FA-C) of the Boka Bil Formation are constituted by the deposits of the marginal marine setup of the estuary (FA-C1), tidal river, tidal creek $(\mathrm{FA}-\mathrm{C} 2)$, and tidal flat environment (FA-C3).

4. The increased monsoonal effect during the middle to late Miocene increased sedimentation during the UBM and shifted the prograding delta toward the south of the Himalaya foreland basin. The area uplifted due to the Indian Plate moved beneath the Burmese Plate during the late Miocene to Pliocene age likely caused the environment change from continental shelfslope basinal plain to marginal shallow marine.

5. Paleocurrent analysis shows the continental slope was east-west orientation and detritus were derived from the Himalaya to the north and Trans-Himalaya to the northeast of the present geographical setup and sediment likely carried through the Paleo-Brahmaputra.

\section{AUTHOR'S CONTRIBUTIONS}

Md. M. Haque and M.K. Roy proposed, designed the research, and conducted fieldwork for data collection.
Md. M. Haque performed analyzed the data and write the manuscript; M.K. Roy edited the paper and both authors have read and agreed to the published version of the manuscript.

\section{REFERENCES}

Ahmed, W., Zaher, M.A., 1980, Stratigraphy of Bangladesh. In: Petroleum and Mineral Resources of Bangladesh, Seminar and Exhibition, 08-12 October 1980, Dacca, pp. 35-40.

Akhter, M.H., Bhuiyan, A.H., Hussain, M., Imam, M.B., 1998, Turbidite sequence located in Bangladesh. Oil and Gas Journal, pp. 109-111.

Alam, M., Alam, M.M., Curray, J.R., Chowdhury, M.L.R., Gani, M.R., 2003, An overview of the sedimentary geology of the Bengal Basin in relation to the regional tectonic framework and basin-fill history. Sedimentary Geology, v. 155, pp.179-208.

Alam, M.M., 1990, Textural control of bedforms and internal structures in a sandy braided river: Some sedimentological implications. Dhaka University Studies, Part-B, pp. 115-121.

Alam, M.M., 1992, Sedimentology of a large braided fluvial system: The Jamuna River, Bangladesh. Bangladesh Journal Scientific Res., v.10 (1), pp. 79-88.

Alam, M.M., Ferdous, M.H.S., 1995, Lithofacies analysis and depositional environment of the Lichubagan Sandstone Formation (Upper Tertiary) in the Sitapahar anticline, south-eastern Folded Belt of Bangladesh. J. Indian Assoc. Sedimentol. v.14, pp. 9-18.

Alam, M.M., Ferdous, M.H.S., 1996, Neogene clastic succession of the Sitapahar anticline southeastern Bangladesh: an example of marine-continental transition. Dhaka Univ. J. Sci., v. 44 (1), pp. 43-52.

Ali, S., Basak, S.B., Roy, M.K., 2020, Facies Analysis and Depositional Environment of the Bhuban Formation, Sitapahar Anticline, Kaptai, Chittagong Hill Tracts, Bangladesh. IOSR Journal of Applied Geology and Geophysics, v. 8 (1), pp. 20-29.

Allen, J.R.L., 1970, Physical Processes of Sedimentation. London, George Allen and Unwin. 248p.

Armstrong-Altrin, J.S., Lee, Y.I., Verma, S.P., Ramasamy, S., 2004, Geochemistry of sandstones from the upper Miocene Kudankulam Formation, southern India: Implications for provenance, weathering, and tectonic setting. Journal of sedimentary Research, v. 74(2), pp. 285-297.

Beck, R., Burbank, D., Sercombe, W., Riley, G., Barndt, J., Berry, J., Afzal, F., Khan, A., Jurgen, H., Metje, J., Cheema, A., Sha-figue, N., Lawrence, R., Asif Khan, M., 1995, Stratigraphicevidence for an early collision between north-west India and Asia. Nature, 373, pp. 55-58.

Betzler, C., Eberli, G.P., Lüdmann, T., Reolid, J., Kroon, D., Reijmer, J.J.G., Swart, P.K., Wright, J., Young, J.R., Alvarez-Zarikian, C., Alonso-García, M., 2018. 
Refinement of Miocene sea level and monsoon events from the sedimentary archive of the Maldives (Indian Ocean). Progress in Earth and Planetary Science, v. 5 (1), pp. 1-18.

Bhattacharyya, A., Chakroborty, C., 2000, Analysis of Sedimentary successions: A field manual, A.A. Balkema, Rotterdam, Brook-field, 408p.

Biswas, B., 1961, Geology of the Bengal Basin with special reference to stratigraphy and micropaleontology. Dissertation, Calcutta University, 138p.

Blatt, H., Middleton, G.V., Murray, R.C., 1980, Origin of sedimentary rocks (2nd ed). Printice - Hall, Englewood Cliffs, New York, 782p.

Boersma, J.R., 1969, Internal structures of some mega ripples on a shoal is the Westerschelde estuary, the Netherlands. Geologie Mijnb., v. 48, pp. 408-414.

Boggs Jr. S., 2001, Principles of Sedimentology and Stratigraphy, 3rd Edition: New Jersey: Prentice-Hall, $726 \mathrm{p}$.

BOGMC, 2000, Petroleum Exploration Opportunities in Bangladesh. Bangladesh Oil, Gas and Mineral (Petrobangla), Dhaka.

Bouma, A.H., 1962, Sedimentology of Some Flysch Deposits. A graphic Approach to Facies Interpretation. Amsterdam. Elsevier Scientific Publ. 168p.

Brombley, M.H., 1991, Architectural features of the Keayenta Formation. (Lower Jurassic), Colorodo Plateau, U. S. A: relationship to tectonics in the Bardox Basin. In: A. D. Miall and N. Tyler (Editors) Atlas of Facies Architecture. Spec. Publ. Soc. Econ. Miner. Paleontol (SEPM), v. 73, pp. 77-99.

Cant, D.J., Walker, R.G., 1976, Development of a Braidedfluvial facies model for the Devonian Battery Point Sandstone, Quebec. Can. Jour. Earth Sci., v. 13, pp. 102-119.

Clift, P.D., Plumb, R.A., 2008, The Asian monsoon: causes, history and effects. Cambridge: Cambridge University Press.

Collinson, J.D., Thompson, D.B., 1982, Sedimentary Structures. George Allen and Unwin, London, 194p.

Cooper, J.A.G., 1993, Sedimentation in a River Dominated Estuary. Sedimentology. v. 40, pp. 979-1017.

Covault, J., 2011, Submarine fans and canyon-channel systems: a review of processes, products, and models. Nature Education Knowledge, v. 3(10), 4p.

Curray, J.R., 1991, Possible greenschist metamorphism at the base of a 22-km sedimentary section, Bay of Bengal. Geology, v. 19 (11), pp. 1097-1100.

Curray, J.R., 1994, Sediment volume and mass beneath the Bay of Bengal. Earth and Planetary Science Letters, v. 125 (1-4), pp. 371-383.

Curray, J.R., 2005, Tectonics and history of the Andaman Sea region. Journal of Asian Earth Sciences, v. 25(1), pp. 187-232.

Curray, J.R., 2014, The Bengal depositional system: from rift to orogeny. Marine Geology, v. 352, pp. 59-69.

Curray, J.R., Emmel, F.J., Moore, D.G., Raitt, R.W., 1982, Structure, tectonics, and geological history of the northeastern Indian Ocean. In: Narin, A.E.M., Stehli, F.G. (Eds.), The Indian Ocean. The Ocean Basin and Margins, Plenum, New York, v. 6. pp. 399-450.

Daidu, F., Yuan, W., Min, L., 2013, Classifications, sedimentary features and facies associations of tidal flats. Journal of Palaeogeography, v. 2(1), pp. 66-80.

Dalrymple, R.W., Zaitlin, B.A., Boyd R., 1992, Estuarine Facies Model: Conceptual Basis Sand Stratigraphy Implication. Journal of Sedimentary Petrology, v. 62 (6), pp. 1130-1146

Dasgupta, P.K., Nandy, D.R., 1995, Geological framework of the Indo-Burmese convergent margin with special reference to ophiolitic emplacement. Indian Journal Geology, v. 67 (2), pp. 110-125.

Davies, C., Best, J., Collier, R., 2003, Sedimentology of the Bengal shelf, Bangladesh: comparison of late Miocene sediments, Sitakund anticline, with the modern, tidally dominated shelf. Sedimentary Geology, v. 155 (3-4), pp. 271-300.

Davis Jr., R.A. (Editors), 1978, Costal Sedimentary Environments, New York, Heidelberg, Berlin, Springer, 420p.

De Raaf, J.M., Boersma, J.R. Van Gelder, A., 1977, Wave generated structural sequences from a shallow marine succession, Lower Carboniferous, County Cork, Ireland. Sedimentology, v. 24, pp. 451-483.

Evans, P., 1964, Tectonic framework of Assam. Jour. Geophy. Soc. India, v. 5, pp. 80-96.

Gani, M.R., 1999, Depositional history of the Neogene succession exposed in the southeastern fold belt of the Bengal Basin, Bangladesh. M.Sc. Thesis, Univ. of Dhaka, Dhaka, Bangladesh, 61p.

Gani, M.R., Alam, M.M., 1999, Trench-slope controlled deep-sea clastics in the exposed lower Surma Group in the southeastern fold belt of the Bengal Basin, Bangladesh. Sediment. Geol. v. 127, pp. 221-236.

Gani, M.R., Alam, M.M., 2003, Sedimentation and basinfill history of the Neogene clastic succession exposed in the southeastern fold belt of the Bengal Basin, Bangladesh: a high-resolution sequence stratigraphic approach. Sediment. Geol. v. 155, pp. 227-270.

Gingras, M.K., MacEachern, J.A., Dashtgard, S.E., Zonneveld, J.-P., Schoengut, J.A., Ranger, M.J., Pemberton, S.G., 2012, Estuaries, In: Knaust, D., Bromley, R.G. (Eds.), Trace Fossils as Indicators of Sedimentary Environments, Elsevier, v. 64, pp. 463505 .

Govin, G., Najman, Y., Copley, A., Millar, I., Van der Beek, P., Huyghe, P., Grujic, D., Davenport, J., 2018, Timing and mechanism of the rise of the Shillong Plateau in the Himalayan foreland. Geology, v. 46(3), pp. 279-282.

Graham, S.A., Dickinson, W.R., Ingersoll, R.V., 1975, 
Himalayan - Bengal model for flysch dispersal in the Appalachian -Ouchita system. Bull. Geol. Soc. Amer. v. 86, pp. 273-286.

Haq, B.U., Hardenbol, J., and Vail, P.R., 1987, Chronology of fluctuating sea levels since the Triassic. Science, $v$. 235, pp. 1156-1167.

Haque, M.M., Roy, M.K., 2020, Sandstone-Shale geochemistry of Miocene Surma Group in Bandarban anticline, SE Bangladesh: Implications for provenance, weathering, and tectonic Setting, Earth Sciences, v. 9 (1), pp. 38-51.

Haque, M.M., Roy, M.K., Joly, N.S., Roy, P.J., Malik, A.R., 2010, Sequences Stratigraphy of the Surma Group of Rocks, Bandarban Anticline, Chittagong Hill Tracts, Bangladesh., International Journal of Earth sciences and Engineering (IJEE), v. 03 (03), pp. 341-356.

Harms, J.C., Southard, J.B. Walker, R.G., 1982, Structures and Sequences in Clastic Rocks .-SEPM Short Course, 9. Lecture Notes. Society of Economic Paleontologists and Mineralogists, Calgary.

Hesse, R., 1975, Turbiditic and non-turbiditic mudstones of Cretaceous flysch sections of the East Alps and other basins. Sedimentology, v. 22, pp. 387-416.

Holtrop, J.F., Keizer, J., 1970, Some aspect of the strtigraphy and correlation of the Surma basin wells, East pakistan. ESCAPE Miner. Resour. Dev. Ser. v. 36, pp.143-154.

Hossain M.S., Khan M.S.H., Chowdhury K.R., Abdullah R., 2019, Synthesis of the Tectonic and Structural Elements of the Bengal Basin and Its Surroundings. In: Mukherjee S. (Eds) Tectonics and Structural Geology: Indian Context. Springer Geology, Springer, pp. 135-218.

Hossain, H.M.Z., Roser, B.P., Kimura, J.I., 2010, Petrography and whole-rock geochemistry of the Tertiary Sylhet succession, northeastern Bengal Basin, Bangladesh: Provenance and source area weathering. Sedimentary Geology, v. 228 (3-4), pp. 171-183.

Hossain, H.Z., Kawahata, H., Roser, B.P., Sampei, Y., Manaka, T., Otani, S., 2017, Geochemical characteristics of modern river sediments in Myanmar and Thailand: implications for provenance and weathering. Geochemistry, v. 77(3), pp. 443-458.

Hossain, I., Roy, M.K., Ul-Islam, Md.S., Hossain, Md.S., Hossain, H.M.Z., 2008, Paleoenvironment of Boka Bil Formation in the Barogang- Hari river section near Lalkhal, Jaintiapur, Sylhet, Bangladesh. Earth Evolution Science. v. 2, pp. 3-14

Johnson, S.Y., Alam, A.M.N., 1991, Sedimentology and tectonics of the Sylhet Trough, Bangladesh. Geol. Soc. Amer. Bull., v. 130, pp. 1513-1527.

Khan, A.A., Agarwal, B.N.P., 1993, The crustal structure of western Bangladesh from gravity data. Tectonophysics, v. 219, pp. 341-353.

Khan, M.R., Muminullah, M., 1988, Stratigraphic lexicon of Bangladesh. Rec. Geol. Surv. Bangladesh 5 (Part 1), 70p.
Khin, K., Sakai, T., Zaw, K., 2014, Neogene syn-tectonic sedimentation in the eastern margin of ArakanBengal basins, and its implications on for the IndianAsian collision in western Myanmar. Gondwana Research, v. 26 (1), pp. 89-111.

Klein G.D., 1982, Turbidite Sandstone Bodies. In: Sandstone Depositional Models for Exploration for Fossil Fuels. Springer, Dordrecht. https://doi. org/10.1007/978-94-010-9758-1_6

Kuehl, S.A., Hariu, T.M., Moore, W.S., 1989, Shelf sedimentation off the Ganges- Brahmaputra river system: evidence for sediment bypassing to the Bengal fan: Geology, v. 17, pp. 1132-1135.

Kumar, N., Sanders, J.E., 1974, Intel sequence, a vertical succession of sedimentary structures and textures created by the lateral migration of tidal inlets. Sedimentology, v. 21, p. 491-532.

Lindsay, J., Holliday, D., Hulbert, A., 1991, Sequence stratigraphyand the evolution of the GangesBrahmaputra delta complex. American Association of Petroleum Geologists Bulletin, v. 75, pp. 12331254.

McKee, E.D., Crosby, E.J. Berryhill, H.L., 1967, Flood deposits, Bijou Creek, Colordao, June 1965. J. Sediment. Petrol. , v. 37, pp. 829-851.

Miall, A.D., 1978, Lithofacies types and vertical profile models in braided river deposits: a summary, In: Miall (Editor). Fluvial sedimentology. Cana. Soc. Petrol. Geol., Mem. v. 5, pp. 597-604.

Miall, A.D., 1986, Facies architecture in clastic basin. In: Kleinspehn K.L., Paola, C. (eds.), New Perspectives in Basin Analysis, New York.

Miall, A.D., 1990, Principle of Sedimentary Basin Analysis. 2nd ed. Sprinver, Berlin, Heidelberg, New York, $688 \mathrm{p}$.

Miall, A.D., 1991, Hierarchies of architectural units in terrigenous clastic rocks and their relationship to sedimentation role. In: Miall, A.D., Tylor, N. (eds.) The three-dimensional facies architecture of terrigenous clastic sediment and its implications for hydrocarbon discovery and recovery. Soc. Econ. Paleont. Min. Paleont., v. 3, pp. 6-12.

Miall, A.D., 1993, The architecture of fluvial deltaic sequence inthe upper Mesavardi group (upper Cretaceous). Book Cliffs, Utah, In: Best, J.L., Bristo, C.S. (eds.), Braided Rivers. Geol. Soc. London. Spec. Publ., v. 75, pp. 305-332.

Middleton, G.V., Hampton, M.A., 1973, Sediment gravity flows: mechanics of flow and deposition, In: Middleton, G.V., Bouma, A.H. (eds.), Turbidites and Deep-water Sedimentation. SEPM. Pacific Section, Short Course, Anaheim, pp. 1-38.

Moore, R.C., Lalicker, C.G., Fisher, A.G., 1997, Invertebrate Fossil. CBS Publication and Distributors, New Delhi, $766 \mathrm{p}$.

Mutti, E., 1977, Distinctive thin-bedded turbidite facies and related depositional environments in the Eocene 
Hecho Group (South-central Pyrenees, Spain), Sedimentology, v. 24, pp.107-131.

Najman, Y., Allen, R., Willett, E.A.F., Carter, A., Barfod, D., Garzanti, E., Wijbrans, J., Bickle, M.J., Vezzoli, G., Ando, S. and Oliver, G., 2012, The record of Himalayan erosion preserved in the sedimentary rocks of the Hatia Trough of the Bengal Basin and the Chittagong Hill Tracts, Bangladesh. Basin Research, v. 24 (5), pp. 499-519.

Najman, Y.M.R., Pringle, M.S., Johnson, M.R.W., Robertson, A.H.F., 1997, Laser 40Ar/39Ar dating of single detrital muscovite grains from early forelandbasin sedimentary deposits in India: implications for early Himalayan evolution. Geology, v. 25(6), pp. 535-538.

Pettijohn FJ., 1984, Sedimentary Rocks (3rd edition), CBS Publishers and Distributors, Delhi, India. 628p.

Pickering, K.T., Hiscolt, R.N., 1989, Deep marine environments In: Clastic Sedimentation and Tectonics. Unwin Hyman, London, 416p.

Potter, P.E., Pettijohn, F.J., 1977, Paleocurrent and Basin Analysis. (2nd Ed). Spinger- Verlag, Berlin, Heidelberg, New York, 425p.

Rahman, M., Suzukia, S., 2007, Composition of Neogene shales from the Surma Group, Bengal Basin, Bangladesh: Implication provenance and tectonic setting. Austrian Journal of Earth Sciences, v. 100, pp. 54-64.

Reading, H.G., 1996, Sedimentary Environments and Facies: Processes, Facies and Stratigraphy (3rd edition) Oxford, Blackwell Science pub. Co., 688p.

Reimann, K-U., 1993, Geology of Bangladesh. GebruderBorntrager, Berlin, Stuttgart, 160p.

Reincek, H.-E., 1960, Uber Zeitlucken in rezenten FlachseeSedimenten. Geol. Rundschau, v. 49, pp. 149-161.

Reincek, H.-E., Singh, I.B., Wunderlich, F., 1968, Classification and origin of flaser and lenticular bedding. Sedimentology, v. 11, pp. 99-104.

Reineck, H.E., Singh, I.B., 1980, Depositional Sedimentary Environments. New York-Heidelberg-Berlin, Springer-Verlag, 439p.

Roy, A.B., Chatterjee, A., 2015, Tectonic framework and evolutionary history of the Bengal Basin in the Indian subcontinent. Current Science, v. 109 (2), pp.271-279.

Roy, M.K., Moniruzzaman, M., Alam, A.K.M., Kabir, M.R., Chudhuri, S., Mahmud, S., Roy, P.J., 2007a, Turbidites in the Upper Bhuban Member of the Sitakund Anticline Chittagong, Southeastern Bangladesh. Journal of Life and Earth Science, Rajshahi University., v. 2 (2), pp. 1-16.

Roy, M.K., Samsuddin, S.S., Islam, M.S., Haque, M.M., Saha, S.S., Roy, P.J., 2006, Submarine Fan model for the early Miocene Bhuban Formation along the Hari River, Jaintiapur, Sylhet Bangladesh. Gondwana Geol. Mag. v. 21 (2), pp. 83-94.
Roy, M.K.R., Akter, Mst.S., Roy, P.J., Akther, S., Haque, Md. N., Malik, A.R.M., Mahmud, S., 2007b, Facies analysis of Boka Bil Formation as exposed along the Barogang- Hari River section, Northeastern Sylhet, Bangladesh. The Icfai Journal of Earth Sciences, v. 1 (1), pp. 22-46.

Rust, B.R., 1978, Depositional models for braided alluvium. In: Maill, A.D. (ed) Fluvial Sedimentology, Canadian Soc. Petrol. Geol. Mem., v. 5, pp. 605-626.

Searle, M.P., Noble, S.R., Cottle, J.M., Waters, D.J., Mitchell, A.H.G., Hlaing, T., Horstwood, M.S.A., 2007, Tectonic evolution of the Mogok metamorphic belt, Burma (Myanmar) constrained by U-Th-Pb dating of metamorphic and magmatic rocks. Tectonics, v. 26 (3), TC3014, doi:10.1029/2006TC002083

Shamsuddin, A.H.M., 2001, Petroleum systems of Bangladesh. SEAPEX Exploration Conference 2001, Singapore, pp. 1-2.

Shamsuddin, A.H.M., Abdullah, S.K.M., 1997, Geological evolution of the Bengal Basin and its implication to hydrocarbon exploration in Bangladesh. Indian Jour. Geology, v. 69, pp. 93-121.

Shan, X., Yu, X.H., Jin, L., Li, Y.L., Tan, C.P., Li, S.L., Wang, J.H., 2021, Bed type and flow mechanism of deep water sub-lacustrine fan fringe facies: an example from the Middle Permian Lucaogou Formation in Southern Junggar Basin of NW China. Petroleum Science, v. 18(2), pp. 339-361.

Shanmugam, G., 1980, Rhythms in deep sea, finegrained turbidite and debris-flow sequences. Middle Ordovician, eastern Tennessee. Sedimentology, v. 27, pp. 419-432.

Shanmugam, G., 2003, Deep-marine tidal bottom currents and their reworked sands in modern and ancient submarine canyons, Marine and Petroleum Geology, v. 20 , pp. $471-491$.

Shanmugam, G., 2006, Deep-Water Processes and Facies Models: Implications for Sandstone Petroleum Reservoirs, Amsterdam, Elsevier, 476p.

Shanmugam, G., 2008, Leaves in turbidite sands: The main source of oil and gas in the deep-water Kutei Basin, Indonesia: Discussion. AAPG Bulletin, v. 92 (1), pp. 127-137.

Shanmugam, G., 2016, Submarine fans: a critical retrospective (1950-2015). Journal of Palaeogeography, v. 5(2), pp. 110-184.

Shii, Z., 1991, Tidal bedding and tidal cyclicities within intertidal sediments of microtidal estuary. Dyfi River Estuary, West Wales, U.K. Sedimentary Geology, v.73, pp. 43-58.

Sikder, A.M., Alam, M.M., 2003, 2-D modelling of the anticlinal structures and structural development of the eastern fold belt of the Bengal Basin, Bangladesh. Sedimentary Geology, v.155, pp. 179-208.

Stow, D.A.V., 1986, Deep Clastic Seas. In: (Reading HG edn) Sedimentary Environment and Facies, (2nd ed.), Backwell Scientific Publication, London, pp. 
$399-443$

Taral, S., Chakraborty, T., Huyghe, P., van der Beek, P., Vögeli, N., Dupont-Nivet, G., 2019, Shallow marine to fluvial transition in the Siwalik succession of the Kameng River section, Arunachal Himalaya and its implication for foreland basin evolution. Journal of Asian Earth Sciences, 184, 103980.

Team USGS-Bangladesh Gas Assessment, 2001, US Geological Survey-PetroBangla cooperative assessment of undiscovered natural gas resources of Bangladesh. US Geological Survey Bulletin.

Terwindt, T.H.J., 1981, Origin and sequence of sedimentary structures in inshore mesotidal deposits of the North Sea. In: S.D. Nio, R.T.E. Shuttenhelm and Tj.C.E. Van Wuring edited Holocene marine sedimentation in the North Sea Basin, Spl. Pub. Intern. Asso. Sedimentologists, v. 5, pp. 4-26.

Tirsgaard, H., 1993, The architecture of Precambrian highenergy tidal channel deposits: an example from the Lyell Land Group (Eleonore Bay Supergroup), NE Greenland. Sedim. Geology, v. 88, pp. 137-152.

Uddin, A., Lundberg, N., 1998, Cenozoic history of the Himalayan-Bengal system: Sand composition in the Bengal basin, Bangladesh. Geological Society of America Bulletin, v. 110(4), pp. 497-511.

Uddin, A., Lundberg, N., 1999, A paleo-Brahmaputra?
Subsurface lithofacies analysis of Miocene deltaic sediments in the Himalayan-Bengal system, Bangladesh. Sedimentary Geology, 123, 239-254.

Uddin, A., Lundberg, N., 2004, Miocene sedimentation and subsidence during continent-continent collision, Bengal basin, Bangladesh. Sedimentary Geology, 164 (1-2), pp. 131-146.

Walker R. G., 1978, Deep- water sandstone facies and ancient sub-marine fan: model for exploration for stratigraphic traps. Bull. Geol. Soc. Am. v. 62, pp. 932-966.

Walker R.G., 1984, Facies Models. Geoscience Canada Reprints series 1, Geol. Assoc. Can. Publ. 317p.

Walker, R.G., 1975, Generalised facies models for resedimented conglomerate of turbidite association. Bull. Geol. Soc. Am. v. 86, pp. 737-748.

Wetzel, A., Uchman, A., 2012, Hemipelagic and pelagic basin plains. In: Dirk, D., Richard, G.B. (Eds.), Developments in sedimentology, Elsevier, v. 64, pp. 673-701.

Zakaria, A.A., Johnson, H.D., Jackson, C.A.L., Tongkul, F., 2013, Sedimentary facies analysis and depositional model of the Palaeogene West Crocker submarine fan system, NW Borneo. Journal of Asian Earth Sciences, v. 76, pp. 283-300. 